\title{
Antithrombotics from the Sea: Polysaccharides and Beyond
}

\author{
Francisca Carvalhal ${ }^{1,2,+}$, Ricardo R. Cristelo ${ }^{1, \dagger}$, Diana I. S. P. Resende ${ }^{1,2,+} \mathbb{D}$, \\ Madalena M. M. Pinto ${ }^{1,2} \mathbb{D}$, Emília Sousa ${ }^{1,2, *(\mathbb{D})}$ and Marta Correia-da-Silva ${ }^{1,2} \mathbb{D}$ \\ 1 LQOF-Laboratório de Química Orgânica e Farmacêutica, Departamento de Ciências Químicas, \\ Faculdade de Farmácia, Universidade do Porto, Rua de Jorge Viterbo Ferreira, 228, 4050-313 Porto, Portugal; \\ francisca.carvalhal@gmail.com (F.C.); ricardorc@live.com.pt (R.R.C.); dresende@ff.up.pt (D.I.S.P.R.); \\ madalena@ff.up.pt (M.M.M.P.); m_correiadasilva@ff.up.pt (M.C.-d.-S.) \\ 2 CIIMAR - Centro Interdisciplinar de Investigação Marinha e Ambiental, Terminal de Cruzeiros do Porto de \\ Leixões, Av. General Norton de Matos S/N, 4450-208 Matosinhos, Portugal \\ * Correspondence: esousa@ff.up.pt; Tel.: +351-220428689 \\ + These authors contributed equally to this work.
}

Received: 31 January 2019; Accepted: 13 March 2019; Published: 16 March 2019

\begin{abstract}
Marine organisms exhibit some advantages as a renewable source of potential drugs, far beyond chemotherapics. Particularly, the number of marine natural products with antithrombotic activity has increased in the last few years, and reports show a wide diversity in scaffolds, beyond the polysaccharide framework. While there are several reviews highlighting the anticoagulant and antithrombotic activities of marine-derived sulfated polysaccharides, reports including other molecules are sparse. Therefore, the present paper provides an update of the recent progress in marine-derived sulfated polysaccharides and quotes other scaffolds that are being considered for investigation due to their antithrombotic effect.
\end{abstract}

Keywords: marine-derived; polysaccharide; anticoagulant; antithrombotic; antiplatelet; glycosaminoglycans; sulfated fucans; sulfated galactans

\section{Introduction}

Over the last 15 years, according to the World Health Organization (WHO), the world's leading causes of death are ischemic heart disease and stroke, which constitute the number one and two of the top 10 global causes of death and accounted for a combined 15.2 million deaths in 2016 (WHO 2018) [1,2]. To treat ischemic heart disease and stroke, antiplatelet agents and, in certain circumstances, anticoagulants, are used. Heparin (HP) was the first clinically used anticoagulant, and after more than 100 years of its discovery (1916), it remains the most used [3], even though its use is limited to parenteral administration (mainly because of their highly negative charge and large molecular weight) and the new orally active anticoagulants lack the multiple activities of HP, which is thought to be involved beyond the coagulation cascade [4], with antimetastatic [5] and anti-inflammatory activities [6]. The search for orally active and multitarget small molecules as new antithrombotic drugs is an attractive approach to overcome the limitations of current drugs used in therapy [7].

Significant interest has been established in anticancer and antimicrobial compounds isolated from marine sources due to their unique and unusual chemical structures, as well as pharmacological properties [8]. In recent years, other therapeutic areas are being populated by marine bioactive secondary metabolites, cardiovascular being among these areas of unmet medical needs. The most abundant marine sources of new antithrombotic compounds are marine algae and invertebrates, producing both macromolecules, such as polysaccharides, and small molecules (e.g., peptides, 
terpenes, alkaloids, polyphenols, steroids, and polyketides). Although over the last few decades, polysaccharides have been identified as the most therapeutically explored metabolites and suppliers of new antithrombotic agents; in fact, the less explored small molecules have proven to also be an excellent starting point for the development of new and orally effective drugs.

While comprehensive and updated reviews can be found in the literature regarding marine sulfated polysaccharides with antithrombotic activities [9-31], reports of marine antithrombotic small molecules are still sparse in the literature. Therefore, we performed a run-up review of some of the major representatives and newest examples of bioactive polysaccharides reported in the last five years, and a systematic compilation of small molecules isolated from marine organisms with antithrombotic activities.

\section{Methods Used to Evaluate Antithrombotic Activities of Marine Compounds}

Marine-derived compounds were evaluated for their effects on coagulation and platelet aggregation. In a few cases, fibrinolytic activity was also determined.

\subsection{Evaluation of Coagulation}

\subsubsection{Classical Coagulation Times}

The influence of compounds on the plasmatic blood coagulation was usually determined by measuring the activated partial thromboplastin time (APTT), prothrombin time (PT), and thrombin time (TT), which allow the evaluation of the ability to inhibit blood clotting through the intrinsic, extrinsic, and common pathways of the coagulation cascade, respectively (Figure 1) [32].
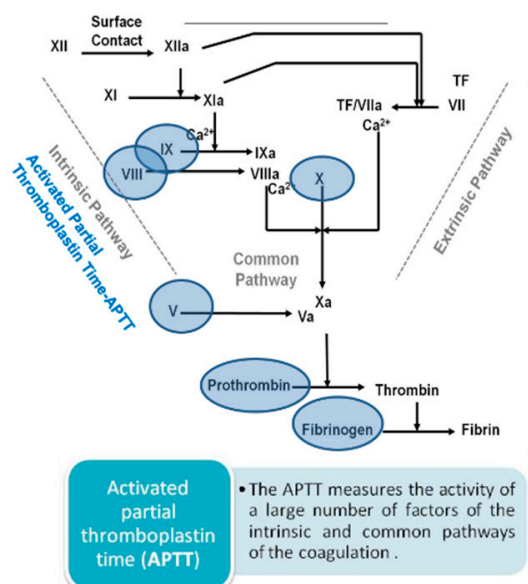
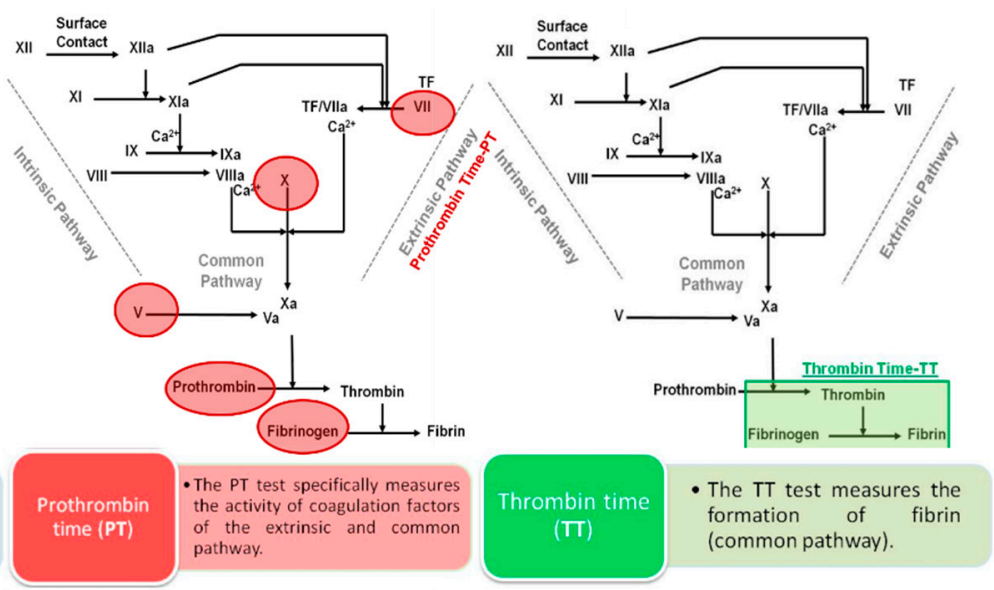

Figure 1. Activated partial thromboplastin time (APTT), prothrombin time (PT), and thrombin time

(TT) assays and their link with the classical coagulation cascade. TF-tissue factor.

Usually, by venipuncture, nine parts of blood are taken into one part of $3.2 \%$ sodium citrate, to prevent blood clotting, from healthy volunteers who did not take any antithrombotic medication. The plasma obtained after centrifugation was pooled and mixed with a compound solution (usually in saline). Coagulation assays were performed using an automated coagulation analyzer and diagnostic kit, and the time that it takes to form a clot was measured in seconds [33-37].

\subsubsection{Effects on Coagulation Factors}

\section{Chromogenic Assays}

Chromogenic assays were used for the characterization of the affinity of the tested compounds toward their target enzymes. Most often, synthetic substrates onto which a chromophore has been linked and purified coagulation proteases were used $[36,38,39]$. Proteases cleave the chromogenic 
substrate, releasing a colored compound that can be monitored using a spectrophotometric reader. When the protease was previously incubated with inhibitory marine compounds, a decrease of the chromogenic substrate cleavage was detected [36,38,39].

\section{Modified Clotting Assays}

In order to identify the specific factor inhibition underlying the APTT prolongation of a marine fish protein (Section 3.2.1), human plasma with specific factor deficiencies from the intrinsic pathway was used [40]. The principle of this assay is to measure to what extent a normal plasma incubated with the compound avoids the normalization of the coagulation time of the specific factor-deficient plasma, which happens when normal plasma (without the compound) is added.

\section{Surface Plasmon Resonance Spectroscopy}

To identify the binding affinity of several marine antithrombotic peptides to blood coagulation factors (Section 3.2.1), surface plasmon resonance sensorgrams were obtained [33,34,41]. In this assay, a ligand protein was directly immobilized on a sensor chip surface and unreacted groups were blocked with ethanolamine. After immobilization of coagulation factors on the sensor chip, the analyte was injected onto the surface of the sensor chip in HEPES-buffered saline buffer followed by dissociation. Resonance was monitored as a function of time, and the binding affinity was represented as a resonance unit or response unit in real time.

\section{PAGE Analysis of Clotting Factor Inhibition}

In order to identify the inhibition of clotting factor (F) XII activated (XIIa) by a marine fish protein (Section 3.2.1), a native polyacrylamide gel electrophoresis (PAGE) method was used. A mixture of the specific factor and analyte were incubated in the presence or absence of $\mathrm{Zn}^{2+}$. After the reaction, aliquots migrated on a $12.5 \%$ separating gel at $\mathrm{pH} 8.8$ using an electrolyte buffer. Several calibration molecular weight markers were used [40].

\subsection{Evaluation of Platelet Aggregation}

Concerning antiplatelet activity, several marine compounds were incubated with platelet-rich plasma (PRP) or washed platelets (WP) or whole blood and then, platelet aggregation was triggered by adding various types and doses of agonists, such as adenosine diphosphate (ADP), collagen, thrombin, and/or platelet activating factor (PAF) (Figure 2).

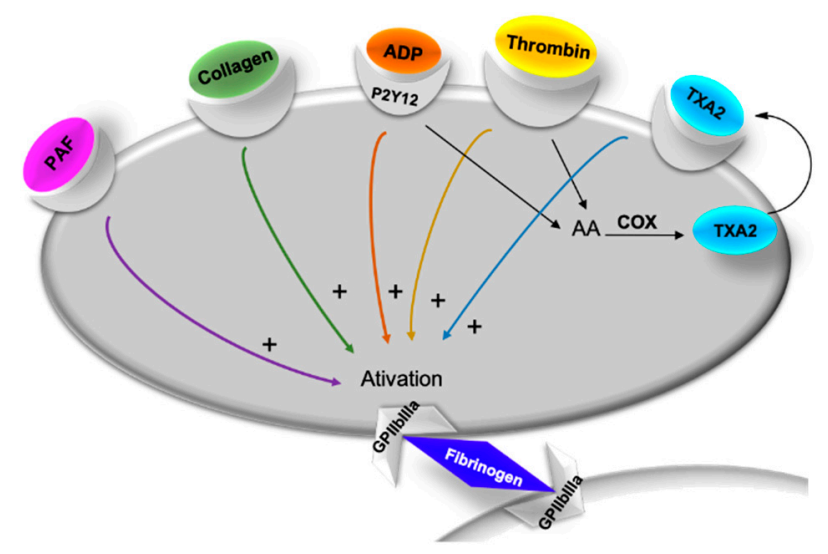

Figure 2. Platelet activation agonists. ADP-adenosine diphosphate; AA-arachidonic acid; ADP - adenosine diphosphate; $\mathrm{COX}$-cyclooxygenase; PAF-platelet activating factor; $\mathrm{TXA}_{2}$ thromboxane A2.

The platelet aggregation was measured turbidometrically by an aggregometer (example in Reference [37]). 


\subsection{Evaluation of Fibrinolysis}

Fibrin(ogen)olytic properties of eckol, dieckol, and phlorofucofuroeckol A (Section 3.2.4) were evaluated by their inhibitory activity on the main plasmin inhibitors, $\alpha_{2}$-macroglubin and $\alpha_{2}$-antiplasmin $[42,43]$. Plasmin is an important enzyme of the fibrinolytic system that cuts the fibrin mesh.

\subsection{In Vivo Antithrombotic Activity}

The in vivo activity of a polysaccharide from a green alga was investigated after being injected to anaesthetized rats (Section 3.1.2). Blood was taken from the abdominal aorta, and the clotting times APTT, TT, and PT were evaluated. In vivo fibrin(ogen)olytic properties of this polysaccharide were also tested in the rat blood using fibrin(ogen) degradation products, D-dimer, and plasminogen activator inhibitor-1 (PAI-1) commercial kits (Section 3.1.2) [44]. Other assays were also used in in vivo studies, as follows.

\subsubsection{Recovery Time from Paralysis}

A pulmonary thromboembolism model induced by the intravenous injection of collagen and epinephrine agonists was used to evaluate in vivo antithrombotic effects of two marine terpenes (Section 3.2.2) [45]. In this model, analytes and a positive control were intravenously administered into the tail veins of mice. Then, a mixed solution of pulmonary thrombosis agonists was injected into the tail vein, which resulted in mouse paralysis for a period of $40 \mathrm{~min}$ or death. The antithrombotic efficacy was evaluated based on the recovery time from pulmonary thrombosis-induced paralysis, compared with positive control.

\subsubsection{Bleeding Time}

In this assay, male mice were anesthetized with pentobarbital and the analyte or HP (as control) were given. The tail vein of the mouse was wounded, and the blood was absorbed into a filter paper every $1.5 \mathrm{~s}$. Bleeding time can be calculated at the point in which no blood is detected on the paper (performed for plancinin in Section 3.2.1) [46]. The bleeding time (see for example urchin sulfated glycans in Section 3.1) can also be evaluated by immersing the tail in water and following that, hemoglobin is measured by spectrophotometry [47].

\subsubsection{Venous Thrombosis}

The in vivo venous thrombosis assay used thromboplastin as the thrombogenic stimulus (done for three urchins sulfated glycans, Section 3.1). The inferior vena cava was isolated, and different doses of the test compounds were infused and allowed to circulate for $5 \mathrm{~min}$. Then, the formed thrombus was removed and weighed and compared with the thrombus weight in the absence of analyte administration [47].

\section{Marine Compounds with Antithrombotic Activity}

\subsection{Polysaccharides}

Carbohydrates (also known as glycans) are the most abundant natural biomolecules, exhibiting a large structural diversity due to the multiplicity of interactions of their monosaccharide units. These building blocks can be linked to each other at various positions and with several linkages on the pyranose or furanose rings, creating branched structures and thus presenting diverse biological functions $[9,48]$. Among carbohydrates, polysaccharides (PS) represent some of the most abundant bioactive substances [48]. Glycosaminoglycans (GAGs) are complex, linear, and negatively charged polysaccharides present in animal tissues [49,50]. The commonest examples of GAGs found in mammals are divided into five main groups (Figure 3): HP/heparan sulfate (HS), chondroitin sulfate 
(CS), dermatan sulfate (DS), keratan sulfate (KS), and hyaluronan (the only GAG that is not sulfated). Depending on the source, GAGs can have distinct structures. In marine algae and invertebrates, into addition to structurally unique GAGs such as fucosylated chondroitin sulfate (FCS), DS, and HS, some GAG-resembling sulfated glycans, like sulfated fucans (SFs) and sulfated galactans (SGs), can also be found (Figure 3) [50].

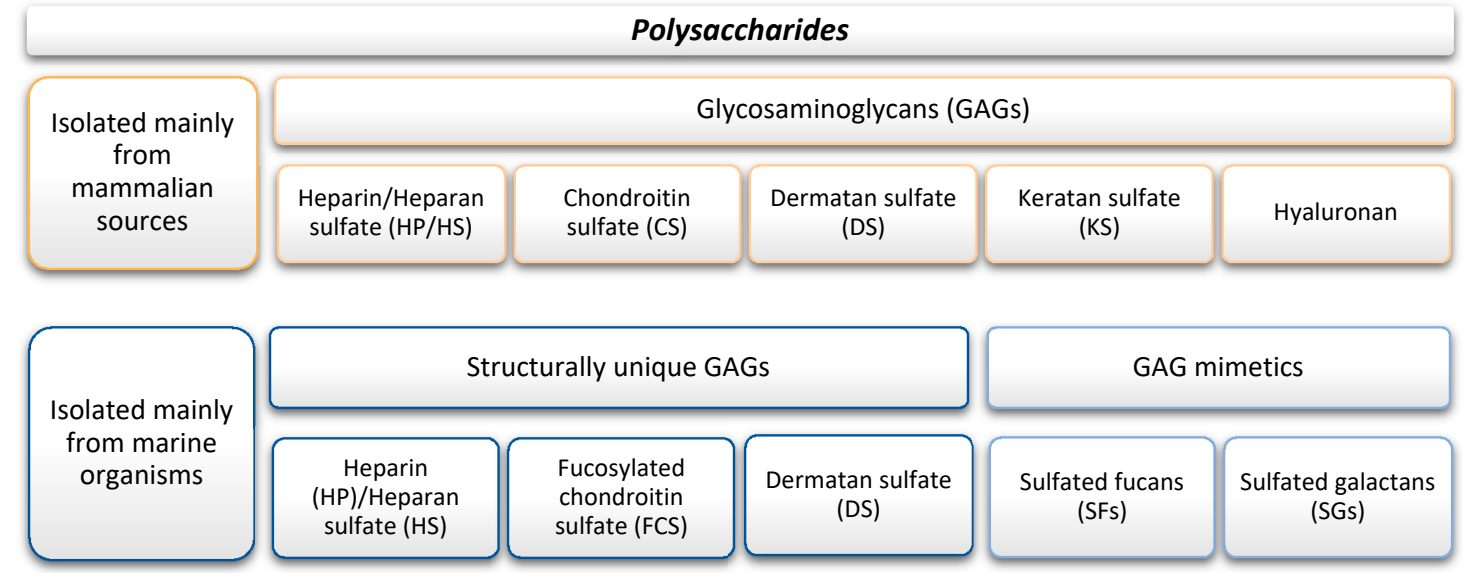

Figure 3. Most representative classes of polysaccharides isolated mainly from mammalian sources and marine organisms.

Structurally, GAGs are composed of repeating units of $N$-acetylated or $N$-sulfated hexosamine (glucosamine $(\mathrm{GlcN})$ ) with either uronic acid or galactose. The structures of all the sulfated GAGs and of hyaluronan are represented in Figure 4. Uronic acid can be either glucuronic acid (GlcA) or iduronic acid (IdoA). For example, HP consists of alternating N,6-di-O-sulfated $\alpha$-D-GlcN (GlcNS6S) and 2-sulfated $\alpha$-IdoA units (IdoA2S), both 4-linked (Figure 4), while HS is composed of repeating units of $\beta$-D-GlcA and $N$-acetylated $\alpha$-D-GlcN both 4-linked [50]. Although they are not within the scope of this review, the representation of the mammalian GAGs will be of use for further comparison of structural features between mammalian and marine-derived sulfated polysaccharides.

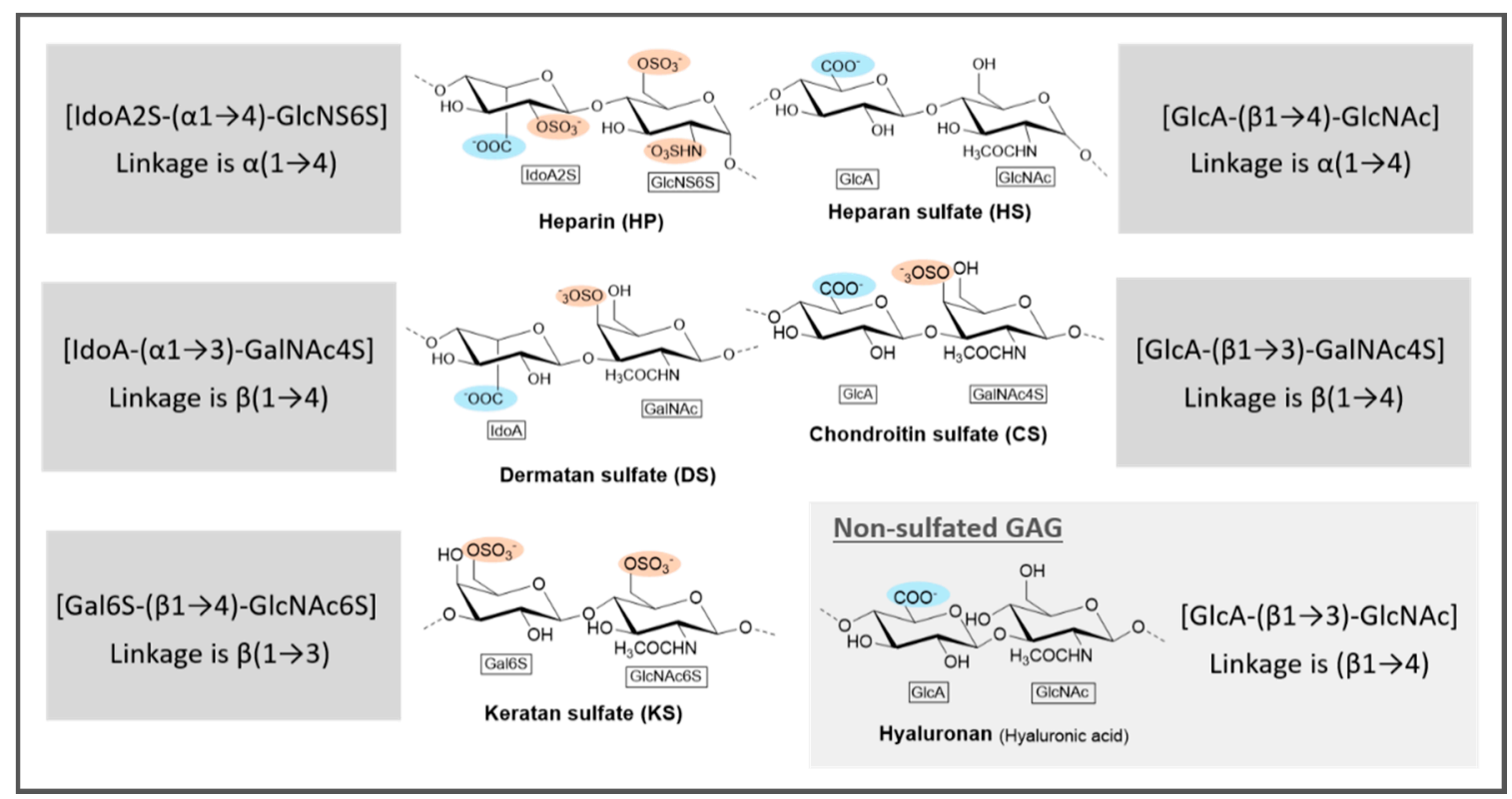

Figure 4. General representation of glycosaminoglycans of mammals. IdoA2S-2-sulfated iduronic acid; GlcNS6S-N,6-disulfated glucosamine; GlcA-glucuronic acid; GlcNAc- $\mathrm{N}$-acetylglucosamine; GalNAc4S-4-sulfated N-acetylgalactosamine; IdoA—iduronic acid; Gal6S-6-sulfated galactose; GlcNAc6S-6-sulfated N-acetylglucosamine. Adapted from Reference [50]. 


\subsubsection{Marine GAGs}

Marine GAGs display different structures from those of common mammalian GAGs [51], with unique sulfation patterns. For example, HS, DS, and CS from marine invertebrates have equivalent amounts of uronic acid and hexosamine as HP but with distinct sulfation patterns, being considered a valid source of HP analogues [52]. Until 2014, several examples of structurally unique GAGs with anticoagulant and antithrombotic effects isolated from ascidians [53-57], sea urchins [58], sea cucumbers [51,59-61], mollusks [62], and shrimps [63,64] were described in the literature. The main feature of these new and interesting GAGs isolated from the extracellular matrices of certain marine invertebrates is the structural regularity that, contrary to mammalian GAGs, allows the development of advanced structure-anticoagulation relationship studies $[17,19,51,60]$. The main conclusions of these studies point out the importance of specific structural combinations, such as the 2,4-di-sulfation with $\alpha$-L-Fucp units found in the branched FCS molecules from sea cucumbers or the combination of the 4-sulfation in GalNAc units with occasional 2-sulfation in IdoA, as is the case of DS from ascidians (Figure 5) [17,51].

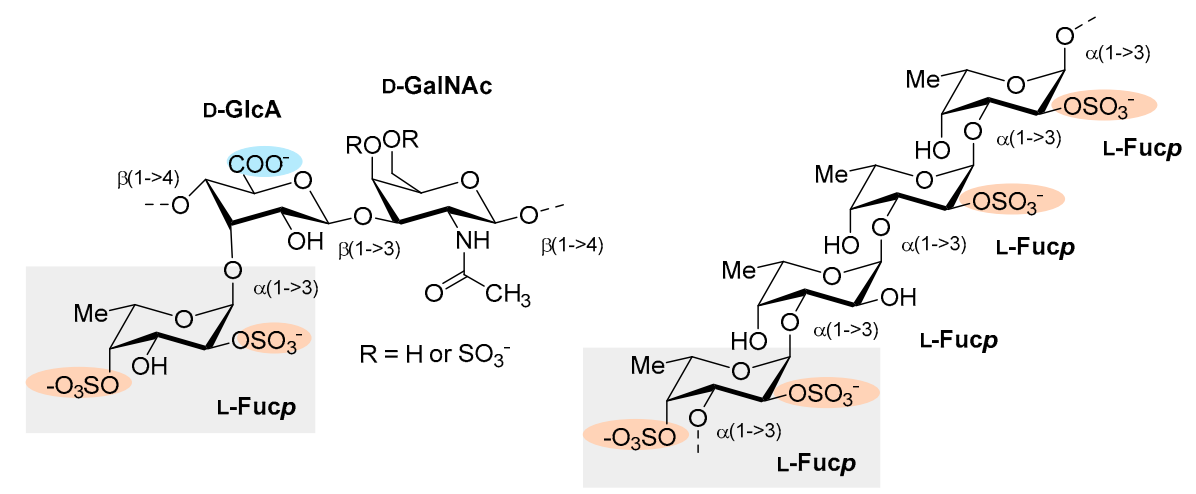

Figure 5. General representation of the anticoagulant molecules from the sea urchin holothurian species Ludwigothurea grisea. Adapted from References [17,51].

Over the years, several antithrombotic GAGs have been isolated from marine invertebrates. Since 2014 and to the best of our knowledge, new secondary metabolites with these activities have only been reported mainly from FCS, and almost exclusively from sea cucumbers (Table 1) [10,65-69]. FCSs isolated from the sea cucumber Cucumaria frondosa (FCSc), Thelenota ananas (FCSt), and its depolymerized low molecular weight (LMW) fragments (dFCSc and dFCSt) containing diverse sulfated fucose branches were evaluated by Liu and co-workers for their in vivo anticoagulant and antithrombotic activities [65]. The results demonstrated that both LMW fragments had similar antithrombotic effects and bleeding side effects and also prolong-APTT, anti-FIIa, and anti-FXa activities. Generally, the LMW fragments exhibited better antithrombotic-hemorrhagic ratios than their native forms, even when compared with HP and low molecular weight heparin (LMWH) in a rat arterial thrombosis model. Furthermore, when compared to FCSt, FCSc possessed different sulfation patterns but similar antithrombotic effects. As a conclusion, the authors stated that anticoagulation and antithrombotic effects might not be affected so much by the sulfation pattern of FCS, but the molecular weight and the sulfation degree could have some influence on the obtained results [65].

Other FCS isolated from the body wall of the Pacific sea cucumber Cucumaria japonica inhibited platelets aggregation in vitro mediated by collagen and ristocetin but not adenosine diphosphate [66]. Regarding anticoagulant activity, FCS exhibited higher activity than that one of LMWH in the APTT assay. The effect of FCS on the activity of thrombin and FXa was also studied in the presence and in the absence of antithrombin III (ATIII). FCS showed a comparable level of activity with that of LMWH regarding experiments with thrombin, and in the case of FXa inhibition FCS was $\sim 10$-fold less active than LMWH, both in the presence of ATIII, while no activity was observed in the absence of ATIII. These results evidenced a serpin-dependent mechanism of action of FCS 
in the cases of thrombin and FXa [66]. Later, the same group isolated an FCS (named MM by the authors, Figure 6) from the sea cucumber Massinium magnum. MM was shown to contain a typical CS core with a small portion of CS fragments. Moreover, Fuc3S4S attached to O-3 of GlcA residues were the only type of branches found in the structure of $\mathrm{MM}$, which was determined as $\rightarrow 4)$-[ $\alpha$-L-Fuc3S4S- $(1 \rightarrow 3)]-\beta$-D-GlcA- $(1 \rightarrow 3)-\beta$-D-GalNAc4S6S- $(1 \rightarrow$, whereas the minor repeating unit was $\rightarrow 4)$-[ $\alpha$-L-Fuc3S4S-( $1 \rightarrow 3)]-\beta$-D-GlcA- $(1 \rightarrow 3)-\beta$-D-GalNAc4S- $(1 \rightarrow$ (Figure 6$)$. APTT and TT tests were used to evaluate the anticoagulant activity of $\mathrm{MM}$, which was revealed to be higher (two-fold delay of clot formation $(2 \mathrm{APTT})=2.8 \pm 0.1 \mu \mathrm{g} / \mathrm{mL})$ than that of enoxaparin $(3.9 \pm 0.2 \mu \mathrm{g} / \mathrm{mL})$ but lower than that of HP $(1.2 \pm 0.1 \mu \mathrm{g} / \mathrm{mL})$. The authors also studied the effect of MM on the activity of thrombin and FXa in the presence and in the absence of ATIII, with similar results. Although MM exhibited a comparable level of thrombin inhibition to that of enoxaparin but lower than that of HP, regarding FXa inhibition, MM was $~ 10$-fold less active than enoxaparin. Further, no activity was observed in the absence of ATIII, suggesting a serpin-dependent mechanism of action of MM in the cases of thrombin and FXa. MM did not induce platelet aggregation in PRP.

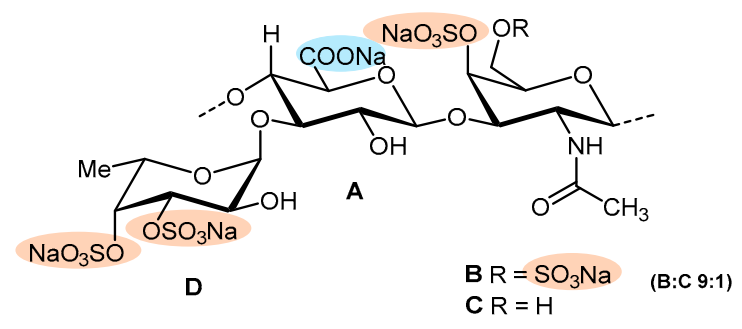

Figure 6. Structure of the repeating trisaccharide units of a fucosylated chondroitin sulfate isolated from sea cucumber Massinium magnum (MM) [67].

A novel FCS (FCShm) was isolated from the sea cucumber Holothuria mexicana, and its anticoagulant activity was evaluated using APTT, PT, and TT of plasma clotting assays [68]. FCShm displayed intrinsic anticoagulation since, compared to LMWH, it significantly prolonged the APTT and TT and barely affected PT. Furthermore, FCShm inhibited the activities of thrombin and FXa through high binding affinity to ATIII [68]. Another example that relates to the study of the anticoagulant activities of the FCS is HsG, isolated from sea cucumber Holothuria scabra [69]. APTT and TT assays exhibited a similar result when comparing $\mathrm{HsG}$ with HP, being prolonged both times [69].

Regarding structure-activity relationship (SAR) studies, there are some controversial opinions in the literature about the influence of the structure of fucosyl branches on biological activities of FCS. Although earlier papers stated the importance of 2,4-disulfation of fucose residues for anticoagulant properties [61,70], recent publications (as discussed above) showed that the molecular weight might have a stronger influence on anticoagulation and antithrombotic events than the sulfation pattern of FCS $[65,67]$.

\subsubsection{Marine GAG Mimetics}

The marine environment is also a rich source of structurally unique GAGs, known as GAG mimetics, such as SFs and SGs isolated from certain macroalgae (brown [31,34,71-90], red [91-103], and green [72,104-118] (Figure 7)), microalgae [119-121] or from invertebrates [47,58,65,122-129] like echinoderms (sea cucumber and sea urchins) or tunicates (ascidians). These interesting sulfated homopolysaccharides have been largely studied in the last years $[22,27,31]$ and discussed in several reviews as potential pharmaceuticals of the future $[14,17,130,131]$.

The reasons for the growing interest in these molecules consist of (1) substantially lower contamination levels of virus and/or prions, since they are exclusively extracted from marine sources [19]; (2) the unique and distinct structures of these glycans compared to the GAG structure [24,132]; (3) the mechanisms of action that, although being similar to the GAGs used in medicine, can exhibit additional or slightly different effects, which can be considered advantageous 
factors in the development of alternative anticoagulants [13]; (4) the fact that some SFs and SGs do not exhibit bleeding risks, contrarily to the HP therapy [133]. In general, algal polysaccharides are structurally more complex, with heterogeneous structures, compared to polysaccharides isolated from marine invertebrates that have simple, linear structures [134].

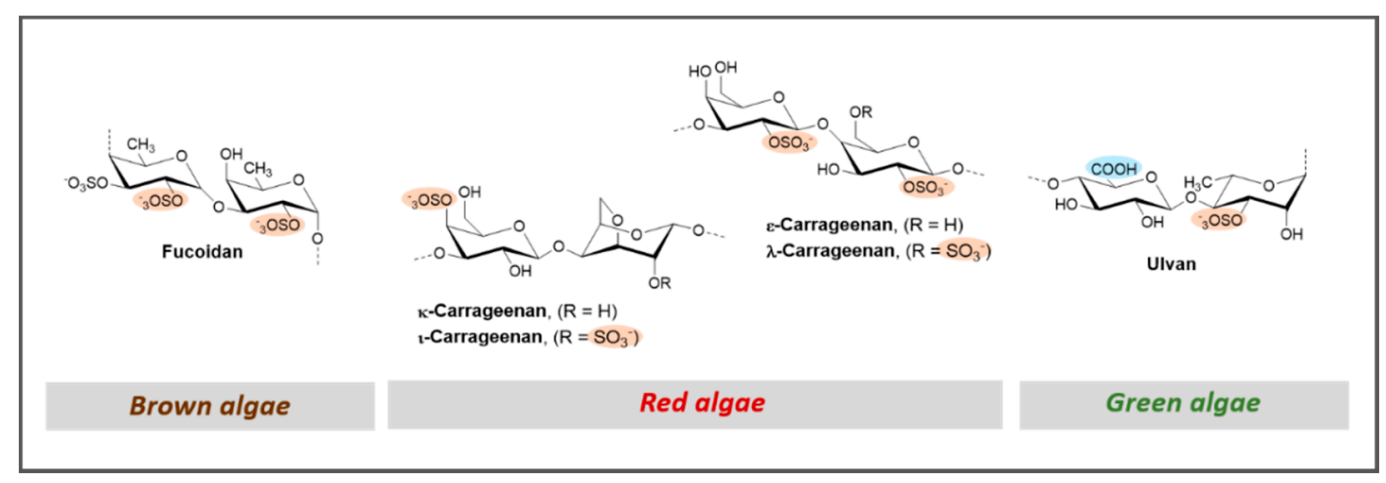

Figure 7. General representation of the structural features of marine sulfated glycosaminoglycans (GAG) mimetics isolated from brown, red, and green algae.

Fucoidan designates a family of sulfated polysaccharides extracted from marine brown algae (Phaeophycophyta) and some echinoderms (sea urchin and sea cucumber). Most of the structures found in brown algae are highly heterogeneous due to several sulfation and glycosylation sites and also the common presence of branching residues in any position, making complete structural elucidation difficult [134]. The term SFs is reserved for polysaccharides with a regular structure, containing a majority of sulfated fucose, which are often extracted from marine invertebrates [12]. The chemical structures of these SFs were found to be species-specific [122]. Since fucoidan preparations are often mixtures of structurally different polysaccharides, the structure elucidation of these is often problematic. Four fractions from a fucoidan preparation named FSA (by the authors) were isolated from the brown algae species Sargassum aquifolium collected from the coastal waters of Vietnam [135]. These fractions were analyzed by chemical and spectroscopic methods (nuclear magnetic resonance) and revealed the presence of three structurally different polysaccharides. HP-like anticoagulant properties of FSA fractions were characterized by determination of APTT, and some fractions showed $2 \mathrm{APTT}=6.5 \pm 0.4 \mu \mathrm{g} / \mathrm{mL}$ for $2.0 \mathrm{M}$ when compared to enoxaparin $(3.9 \pm 0.4 \mu \mathrm{g} / \mathrm{mL})$, even in the most sulfated fractions [135]. The same authors also reported the isolation of a mixture of sulfated polysaccharides (named FHC by the authors) from the brown algae Hormophysa cuneiformis [74], where a highly sulfated fucogalactan was identified as the main structural motif. An APTT test revealed that the main portion obtained after fractionation by anion-exchange chromatography was only about half as active (2APTT $=7.8 \pm 0.3 \mu \mathrm{g} / \mathrm{mL})$ as enoxaparin $(3.8 \pm 0.2 \mu \mathrm{g} / \mathrm{mL})$ and, therefore, had no advantage over many other active fucoidans [74].

Like fucoidans, when SGs are extracted from red algae, they are designated carrageenans. Extracts containing SGs and carrageenans (Figure 7) were isolated from the red algae Corallina from the Lebanese coast of Batroun, with total yields of $2.5 \%$ and $10 \%$, respectively [101]. APTT assay was used to study the anticoagulant activity of both polysaccharides, the activity of SGs being less potent than that of carrageenans.

Regarding green algae, a large body of literature is available on the isolation and evaluation of the antithrombotic effects of ulvan, a typical sulfated polysaccharide isolated from this kind of algae (Figure 7) [136]. The study of the structural features and anticoagulant activity of the sulfated polysaccharide SPS-CF (ulvan from Capsosiphon fulvescens) isolated from green alga Capsosiphon fulvescens revealed the presence of xylose and rhamnose as the most prominent monosaccharides, suggesting the presence of glucuronorhamnoxylan, an ulvan [137]. When tested for their anticoagulant activity, APTT and TT were significantly prolonged. In the TT assay, the clotting time of SPS-CF reached up to $31.7 \pm 1.3 \mathrm{~s}$ (dextran: $14.6 \pm 0.2 \mathrm{~s}$ and HP: $46.4 \pm 2.2 \mathrm{~s}$ ) and in the APTT assay, 
SPS-CF also dose-dependently prolonged the clotting time $(60.9 \pm 1.7 \mathrm{~s})$, although it exhibited weaker activity than HP $(76.3 \pm 2.0 \mathrm{~s}(0.3 \mu \mathrm{g} / \mathrm{mL}))$ but higher in the case of dextran $(43.1 \pm 1.2 \mathrm{~s}$ $(200 \mu \mathrm{g} / \mathrm{mL}))$. Other examples of sulfated polysaccharides containing rhamnose isolated from green algae include the sulfated polysaccharide MSP obtained from Monostroma angicava and the respective low-molecular-weight fragments prepared by controlled acid degradation [44]. The polysaccharides were sulfated rhamnans that consisted of $\rightarrow 3)$ - $\alpha$-L-Rhap-( $1 \rightarrow$ and $\rightarrow 2)$ - $\alpha$-L-Rhap-( $1 \rightarrow$ units with partial sulfation at C-2 of $\rightarrow 3)-\alpha$-L-Rhap-( $1 \rightarrow$ and C-3 of $\rightarrow 2)-\alpha$-L-Rhap- $(1 \rightarrow$. Regarding their anticoagulant activity, MSP prolonged APTT and TT but failed to prolong PT. APTT and TT prolongation times by MSP were also dose-dependent in vivo. The APTT activity by MSP at $8 \mathrm{mg} / \mathrm{kg}$ and $16 \mathrm{mg} / \mathrm{kg}$ was considerably stronger than that of HP, but the TT activity was lower. Fibrinolytic activity in vivo was also assayed, and the levels of plasmin degradation products were noticeably enhanced and the level of PAI-1 was effectively reduced by MSP. The activity of the sulfated rhamnan was largely affected by the molecular weight (should be over $12 \mathrm{kDa}$ ), and a longer chain was essential to complete thrombin inhibition [44]. Microalgae are also valuable sources of sulfated polysaccharides [119-121]. As an example, the sulfated polysaccharides isolated from Grateloupia livida (GL) showed significant inhibition of blood coagulation in a dose-dependent manner for both APTT and TT assays [138].

Considering marine invertebrates like echinoderms (sea cucumber and sea urchins), very recent examples also reinforce the importance of specific structural requirement for their controlling functions over anticoagulation factors [47]. Three structurally related sea-urchin (Strongylocentrotus franciscanus (S.f.), Lytechinus variegatus (L.v.), and Echinometra lucunter (E.l.)) derived 3-linked sulfated $\alpha$-glycans (Figure 8), and their low molecular weight derivatives were screened for their antithrombotic activities [47]. In the APTT assay, S.f., L.v., and E.l. were the most active compounds among the six tested, but not as potent as the control unfractionated heparin (UFH). Regarding AT-mediated anti-IIa and anti-Xa, L.v. and E.l. were the most effective, while S.f. was observed to be poorly active. The in vivo venous thrombosis assay using thromboplastin as the thrombogenic stimulus revealed that the six tested compounds presented activity in a dose-response manner, despite their lower efficacy compared to the HP standards. L.v., S.f., and E.l. presented the capacity to inhibit $20 \%, 25 \%$, and $50 \%$ of the thrombus weight at the doses of $1.0,0.5$, and $0.25 \mathrm{mg} / \mathrm{kg}$, respectively (UFH and LMWH can prevent $100 \%$ of thrombus formation). Concerning platelet aggregation, E.l. inhibited approximately $30 \%$ of platelet aggregation (against $55 \%$ and $30 \%$ for UFH and LMWH controls, respectively). This study confirmed the previously reported negative effect of the 2-sulfated fucose and the positive effect of the 2-sulfated galactose on anticoagulation activity in vitro $[17,126,139]$ and demonstrated the importance of this set of structural requirements on antithrombosis in vivo, and further supports the involvement of high-molecular-weight and 4-sulfated fucose in both activities.

An SF was isolated from the sea cucumber Holothuria albiventer containing fucose and sulfate in a molar ratio of about 1:0.83 [122]. Structural elucidation revealed that the SF was composed by regular $\alpha(1 \rightarrow 3)$ linked hexasaccharide repeating units with a distinctive sulfate substitution pattern (Figure 8). Anticoagulant activity was evaluated by the APTT, PT, and TT assays. Although the concentrations of SFs required to double the APTT $(25.79 \mu \mathrm{g} / \mathrm{mL})$ and TT $(115.47 \mu \mathrm{g} / \mathrm{mL})$ were higher than the positive control LMWH, it showed no significant PT-prolonging activity at the concentrations tested [122]. The intrinsic factor Xase complex (FXase) inhibitory activity revealed a complete inhibition of FXase (half maximal inhibitory concentration, $\mathrm{IC}_{50}=71.99 \mathrm{ng} / \mathrm{mL}$ ) when increasing concentrations of SFs were used, similar to $\mathrm{LMWH}\left(\mathrm{IC}_{50}=68.57 \mathrm{ng} / \mathrm{mL}\right)$. 


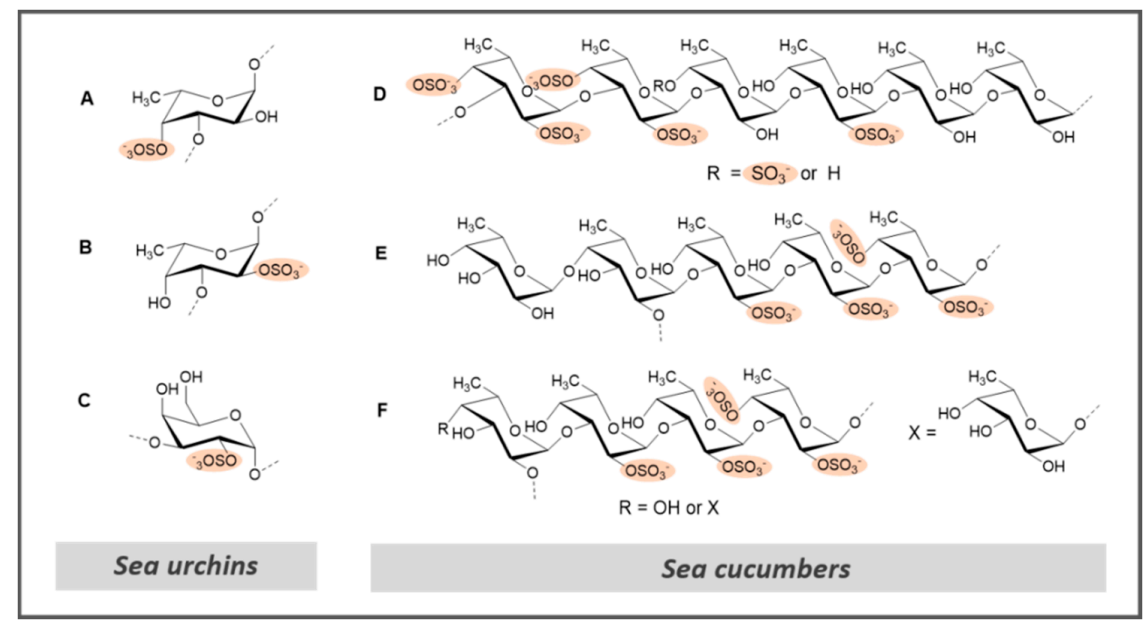

Figure 8. Repeating units of sulfated fucans and sulfated galactans isolated from marine invertebrates proposed by Wu et al. [128]: sea urchin (A) 3-linked 4-sulfated $\alpha$-fucan from the Lytechinus variegatus; (B) 3-linked 2-sulfated $\alpha$-fucan from Strongylocentrotus franciscanus; (C) 3-linked 2-sulfated $\alpha$-galactan from Echinometra lucunter [47]; sea cucumber (D) Holothuria albiventer [122]; (E) Holothuria edulis; (F) L. grisea.

Two other examples of SFs isolated from sea cucumbers (Holothuria edulis and Ludwigothurea grisea) were recently described. These examples exhibit a novel structural motif for this type of polysaccharides composed of a central core of regular $\alpha(1 \rightarrow 3)$ and $\alpha(1 \rightarrow 2)$-linked tetrasaccharide repeating units together with a fucose residue as a side chain (Figure 8), which may contribute to anticoagulant activity [128]. The APTT, PT, and TT were measured and compared with the same activities of UFH and DS. Although both had similar APTT-prolonging activity (aprox. $10 \mathrm{HP} \mathrm{U/mg),} \mathrm{SFs} \mathrm{did} \mathrm{not}$ affect PT and TT in human plasma at the concentrations tested $(1-100 \mu \mathrm{g} / \mathrm{mL})$. Antithrombin activity in the presence of HP cofactor II and anti-FXa and antithrombin activity mediated by AT were also examined with chromogenic substrates. Essentially complete inhibition of thrombin activation by HP cofactor II was achieved with increased concentrations of SFs. Further, they displayed significantly weaker anti-FXa and antithrombin activity mediated by AT rather than HP and LMWH (positive controls). Strong inhibition of thrombin ( $\mathrm{IC}_{50}=0.5-0.7 \mu \mathrm{g} / \mathrm{mL}$ ) was shown in the presence of HP cofactor II with DS as a positive reference, while their thrombin and FXa inhibition activities mediated by AT were much weaker. These assays indicate that SFs strongly inhibit blood clotting through the intrinsic pathways of the coagulation cascade, and the mechanism of action was ascribed to the selective inhibition of thrombin activity by HP cofactor II. Interestingly, although also having high molecular weights, these SFs do not induce platelet aggregation, contrary to the SFs from marine algae [128]. 
Table 1. Anticoagulant and antiplatelet activities of GAGs and GAG mimetics isolated from marine sources in the last five years (2014-2018). $\uparrow$-prolonged/delayed; PS—polysaccharides; $\downarrow$-Reduction; $\Theta$-inhibitor; NR—not represented; NT—not tested; NA—not active.

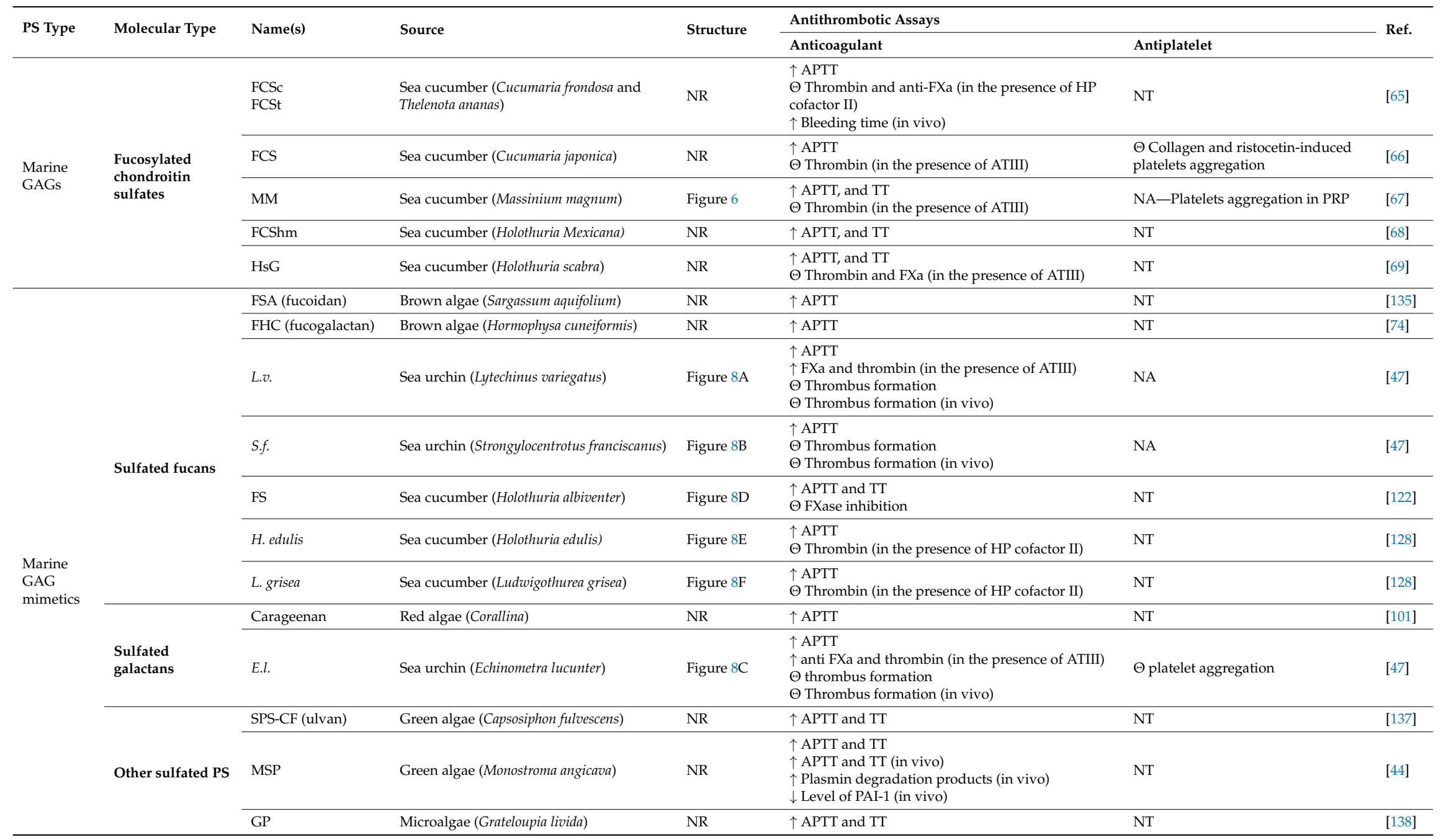




\subsection{Marine Antithrombotics Other than Polysaccharides}

Polysaccharides constitute one of the most studied molecules as potential antithrombotic agents, due to their similarity to HP. However, several strategies have been attempted in order to overcome HP's poor bioavailability [7]. This inconvenience could be surpassed with another type of compounds that could be orally active with or without simple modifications. Several compounds of different chemical natures (peptides, terpenes, alkaloids, polyphenols, steroids, and polyketides), with interesting antithrombotic activities, proved to be active in in vitro and/or in in vivo assays (Table 2). The targets on coagulation cascade (A) and on platelets (B) that were disclosed for some of these marine antithrombotics described in the following subsections are represented in Figure 9.
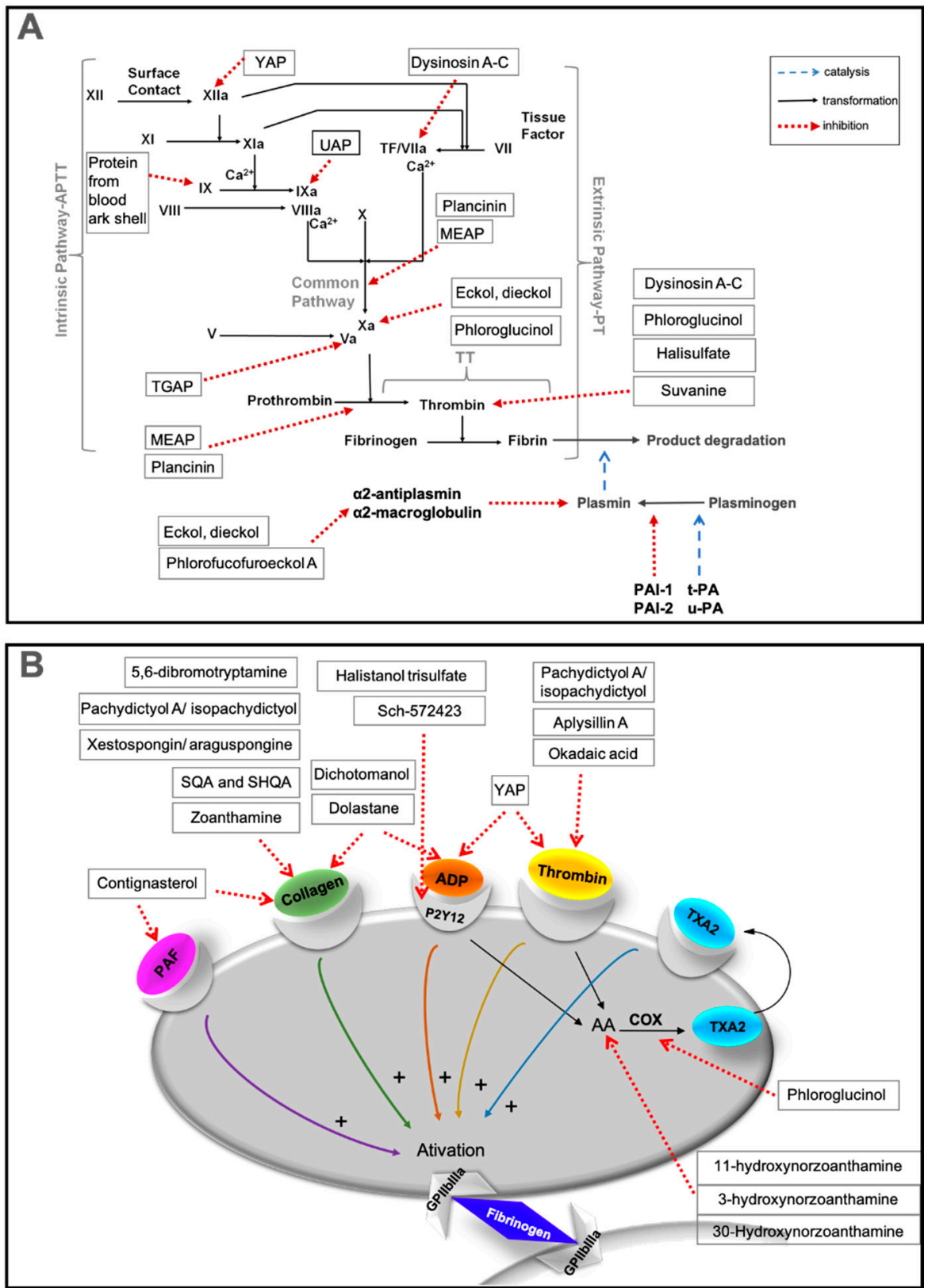

Figure 9. Marine antithrombotics other than polysaccharides and their effects on (A) the coagulation cascade; (B) the platelet activation. AA—arachidonic acid; ADP-adenosine diphosphate; COX-cyclooxygenase; PAF-platelet activating factor; PAI-1 or -2-plasminogen activator inhibitor 1 or 2; $\mathrm{TXA}_{2}$-thromboxane A2; u-/t-PA—tissue-type plasminogen activator. 


\subsubsection{Peptides}

Eight peptides and three proteins were isolated from different marine organisms, such as sponges, starfish, bivalves, fish, and also from a marine echiuroid worm, and were evaluated for their anticoagulant activity and/or for their effects on platelet aggregation (Figure 9A,B).

Plancinin, a peptide with a molecular weight of $7.5 \mathrm{kDa}$, isolated in 1996 from the starfish Acanthaster planci, was incubated with human platelets in the presence of ADP but did not exhibit platelet aggregation activity. However, plancinin showed anticoagulant activity in a dose-dependent manner [140]. Fibrin formation time was prolonged by plancinin $(25 \mu \mathrm{g} / \mathrm{mL})$ and compared with HP ( 0.08 units). Both caused a clotting time of $150 \mathrm{~s}$ (1 unit HP corresponded to $333 \mu \mathrm{g}$ plancinin). In vivo bleeding time in mice was significantly prolonged by plancinin (at $1-2 \mathrm{~h}$ after administration) and by HP (at only $1 \mathrm{~h}$ after administration), and 21 units plancinin and 570 units HP were found to be necessary to cause a $200 \%$ increase. These results showed that plancinin has the highest anticoagulant activity in vivo [140]. Concerning the anticoagulant tests, plancinin (at $200 \mu \mathrm{g} / \mathrm{mL}$ ) prolonged APTT and PT to approximately $110 \mathrm{~s}$ and $30 \mathrm{~s}$, respectively (control APTT of $31.2 \mathrm{~s}$ and PT of $11.7 \mathrm{~s}$ ). On the other hand, plancinin did not affect TT. Further studies proved that plancinin could inhibit the prothrombinase complex by action on the activation step of prothrombin and FX [46].

Four linear peptides containing octahydroindole systems (Figure 10), dysinosin A, isolated from a sponge of the family Dysideidae, and dysinosins B-D, obtained from the sponge Lamellodysidea chlorea, exhibited activity in thrombin and FVIIa, serine protease enzymes of the blood coagulation cascade (Figure 9A) [38,141]. Dysinosins A-D exhibited inhibitory activity against FVIIa ( $k$ i values of $0.108 \mu \mathrm{M}$, $0.090 \mu \mathrm{M}, 0.124 \mu \mathrm{M}$, and $1.320 \mu \mathrm{M}$, respectively) and thrombin ( $k$ i values of $0.452 \mu \mathrm{M}, 0.170 \mu \mathrm{M}$, $0.550 \mu \mathrm{M}$, and $>5.1 \mu \mathrm{M}$, respectively) [38]. Comparing with dysinosins A-C, the desulfated dysinosin $\mathrm{D}$ showed 10 times less potency against both serine protease enzymes, indicating that the sulfate group contributes to both FVIIa and thrombin binding. The presence of a sugar moiety in dysinosin B (Figure 10) was associated with a slightly increasing inhibition of FVIIa and decreased selectivity for thrombin, compared with dysinosins A and C [38]. In contrast to thrombin, no currently approved anticoagulant agents specifically target FVIIa. Dual inhibition of FVIIa and thrombin could be a promising strategy [11].
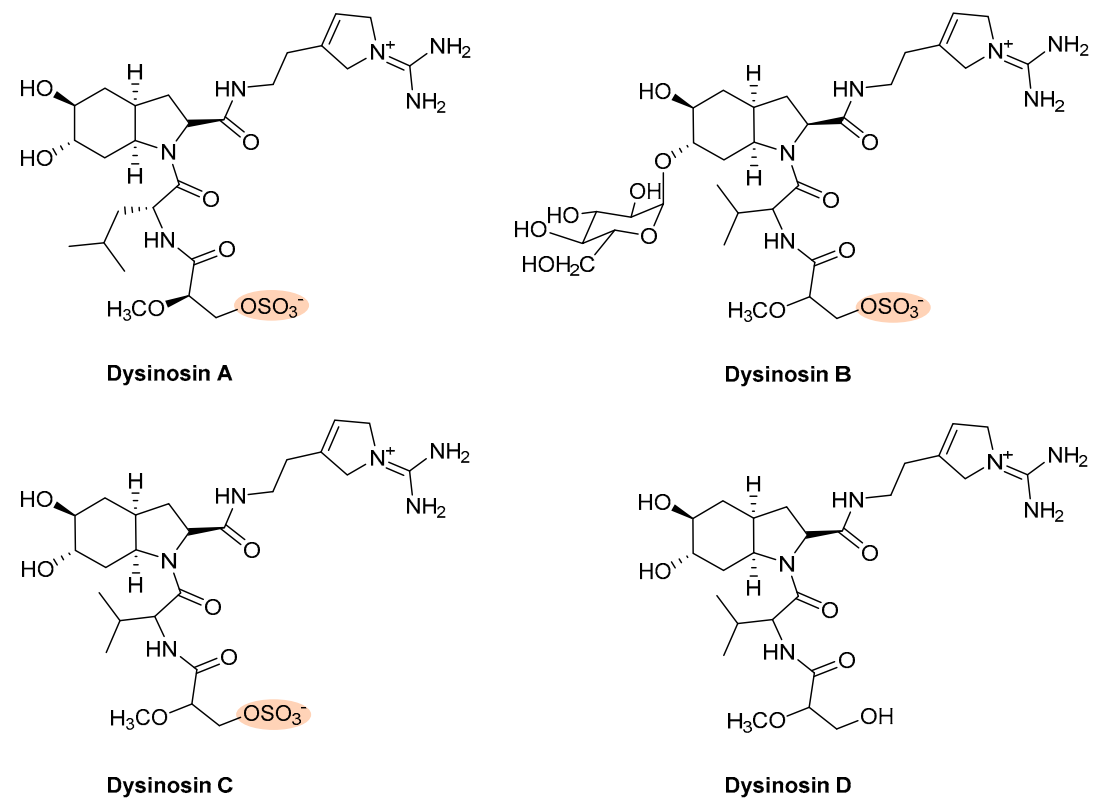

Figure 10. Chemical structures of dysinosin A-D with antithrombotic activity.

In 2008, the Urechis unicinctus anticoagulant peptide (UAP) was isolated in from the marine echiuroid worm $U$. unicinctus, with a $3.3 \mathrm{kDa}$ molecular weight [33]. Even though this peptide did not 
prolong the PT and TT clotting times, the APTT was prolonged in a dose-dependent manner, reaching $192.8 \mathrm{~s}$ in the presence of $1.0 \mathrm{mg} / \mathrm{mL}$ of UAP (control clotting time of $32.3 \mathrm{~s}$ ). The FIXa activity in normal plasma decreased by the addition of UAP in a dose-dependent manner $\left(\mathrm{IC}_{50}=42.6 \mu \mathrm{g} / \mathrm{mL}\right)$. Additional studies concluded that this peptide binds specifically to the FIXa (Figure 9A) [33].

An oligopeptide was isolated in 2009 from the edible parts of the blue mussel Mytilus edulis, with approximately $2.5 \mathrm{kDa}$ molecular mass, and the M. edulis anticoagulant peptide (MEAP) showed prolongation in the normal clotting time on APTT (to $321 \mathrm{~s}$ at $100 \mu \mathrm{g} / \mathrm{mL}$ ) and on TT (to $81.3 \mathrm{~s}$ at $100 \mu \mathrm{g} / \mathrm{mL}$ ), in a dose-dependent manner [35]. In other assays, MEAP inhibited the amidolytic activation of $\mathrm{FX}$, in a dose-dependent manner, with $\mathrm{IC}_{50} \mathrm{of} 13.6 \mu \mathrm{g} / \mathrm{mL}$, and also delayed the catalytic conversion of prothrombin to thrombin in the prothrombinase complex with an $\mathrm{IC}_{50}$ of $42.9 \mu \mathrm{g} / \mathrm{mL}$ (Figure 9A) [35].

In 2016, a novel anticoagulant peptide was isolated from the seaweed Porphyra yezoensis and exhibited a dose-dependent prolongation of APTT from $35 \mathrm{~s}$ to $320 \mathrm{~s}$, at a concentration of $3.0 \mu \mathrm{M}$ and an $\mathrm{IC}_{50}$ of $0.3 \mu \mathrm{M}$. Nevertheless, this peptide failed to prolong PT and TT [142].

The first anticoagulant protein $(26.0 \mathrm{kDa})$ from marine bivalves was isolated in 2002 from the blood ark shell Scapharca broughtonii and, although not exhibiting activity in PT assay, this protein prolonged the clotting time from $32 \mathrm{~s}$ to $325 \mathrm{~s}$ in the APTT test, at $100 \mu \mathrm{g} / \mathrm{mL}$, suggesting that it could inhibit a specific factor in the intrinsic pathway. Further tests concluded that this protein inhibited the FIX in the intrinsic pathway of the blood coagulation cascade [41].

A single-chain monomeric protein $(12.01 \mathrm{kDa})$, designated yellowfin sole anticoagulant protein (YAP), was extracted in 2005 from the marine fish, yellowfin sole Limanda aspera and exhibited anticoagulant and antiplatelet properties [40]. YAP prolonged APTT in a dose-dependent manner, prolonging the clotting time up to $300 \mathrm{~s}$ at $10 \mu \mathrm{M}$. However, when tested in PT and TT, neither were affected, suggesting that YAP is a specific inhibitor of the intrinsic pathway of coagulation. Further tests of the inhibitory effect on specific clotting factors in the intrinsic pathway of coagulation showed complete inhibition of FXIIa activity at YAP concentration of $1.5 \mu \mathrm{M}$ (Figure 9A). Tests on the effect of YAP on platelet aggregation and adhesion were also developed. YAP inhibited, in a dose-dependent manner, platelet aggregation in ADP or thrombin-induced PRP, exhibiting complete inhibition at $660 \mu \mathrm{M}$ and $600 \mu \mathrm{M}$, respectively (Figure 9B) [40]. Simultaneous inhibition of coagulation and platelet aggregation is already known in nature being performed by hematophagous animals, with their saliva containing antithrombotic agents that prevent platelet aggregation [143] and coagulation [144]. Combination of an anticoagulant and an antiplatelet drug proved to be beneficial and is commonly advised in antithrombotic therapy for patients with acute arterial thrombosis [11], with a compound with both activities being a promising antithrombotic alternative [11].

The Tegillarca granosa anticoagulant protein (TGAP), isolated in 2007 also from a marine bivalve, granulated ark T. granosa, with $7.7 \mathrm{kDa}$ molecular weight, prolonged in a dose-dependent manner the TT clotting time from $11.6 \mathrm{~s}$ to 112.8 at $2 \mathrm{mg} / \mathrm{mL}$ but not APTT or PT. Further specific factor inhibitory assays concluded that TGAP could inhibit the FVa in the thrombin-formation pathway (essential in converting prothrombin into thrombin) and could inhibit the interaction between prothrombin and $\mathrm{FVa}$, in a dose-dependent manner with an $\mathrm{IC}_{50}$ value of $77.9 \mathrm{nM}$ [34].

\subsubsection{Terpenes}

Eight terpenes with antithrombotic activity (Figure 11) were disclosed by different assays. Halisulfate and suvanine, two sesterterpenes isolated in 1993 from the sponge Coscinoderma mathewsi Lendenfield, showed inhibition against the serine proteases thrombin and trypsin [145]. Halisulfate was isolated with the counterion 1-methylherbipoline and exhibited $\mathrm{IC}_{50}$ values $>100$ and $25 \mu \mathrm{g} / \mathrm{mL}$ of inhibition against thrombin and trypsin, respectively [145]. Both salts, 1-methylherbipoline suvanine and sodium suvanine, were isolated and exhibited an inhibitory effect against thrombin $\left(\mathrm{IC}_{50}\right.$ values of 27 and $9 \mu \mathrm{g} / \mathrm{mL}$, respectively) and against trypsin ( $\mathrm{IC}_{50}$ values of 12 and $27 \mu \mathrm{g} / \mathrm{mL}$, respectively) (Figure 9A) [145]. 


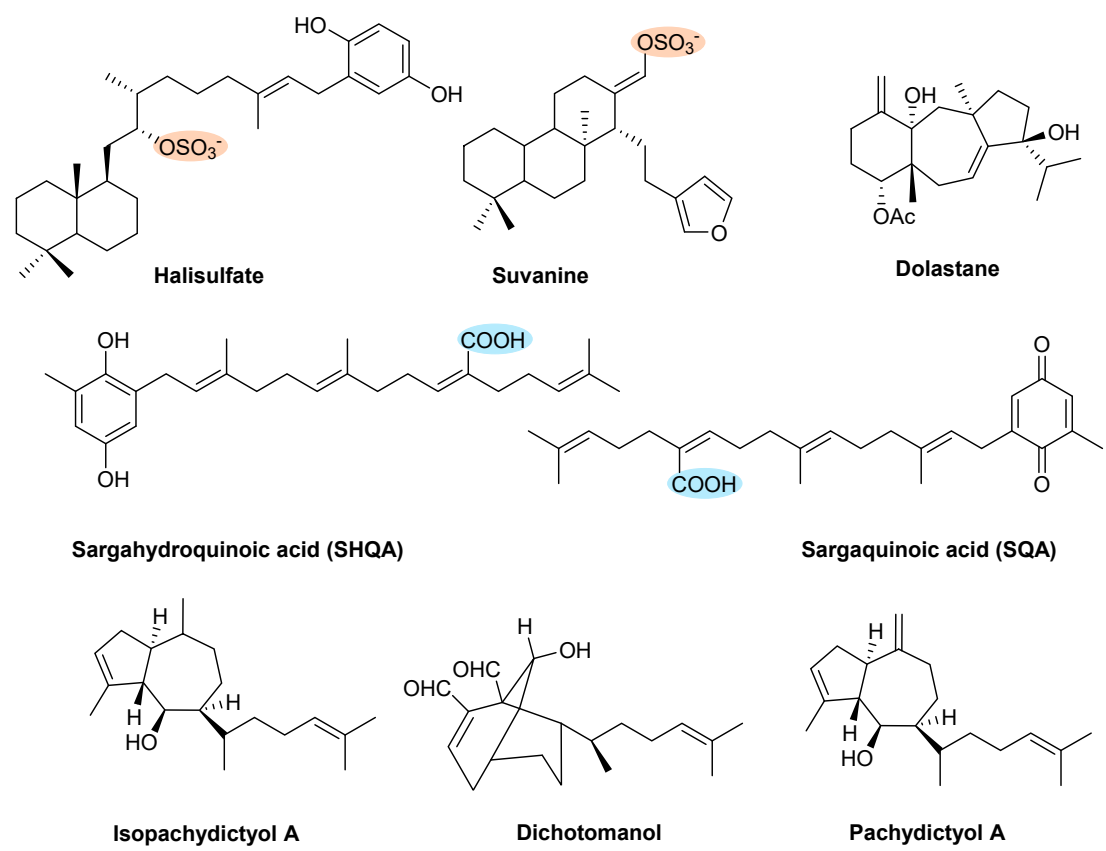

Figure 11. Chemical structures of terpenes with antithrombotic activity.

Sargahydroquinoic acid (SHQA) and sargaquinoic acid (SQA) are major constituents of Sargassum micracanthum [146] and Sargassum yezoense [147] and were first isolated in 2008. SHQA and SQA showed inhibitory collagen-induced platelet aggregation in a dose-dependent manner (Figure 9B) [45]. The percentage of inhibition by SQA was $94.0 \%$ at $40 \mu \mathrm{g} / \mathrm{mL}$, which was much stronger than the effect observed with SHQA $(44 \%$ at $40 \mu \mathrm{g} / \mathrm{mL})$ that exhibited a similar effect as the positive control, aspirin $(43.0 \%$ at $40 \mu \mathrm{g} / \mathrm{mL})$ [45]. Additionally, in vivo antithrombotic effects of both compounds were evaluated by the recovery time from paralysis. SHQA and SQA showed a fast recovery time from paralysis in the mouse pulmonary thromboembolism model (14.7 $\mathrm{min}$ and $6.8 \mathrm{~min}$, respectively), compared to the positive control, aspirin ( $54.3 \mathrm{~min}$ ). The authors hypothesized that, with these results, SHQA and SQA are promising lead structures for antiplatelet agents [45].

Dolastane diterpene, isolated in 2011 from the marine brown algae Canistrocarpus cervicornis [37] was shown to inhibit ADP- or collagen-induced rabbit PRP aggregation, in a concentration-dependent manner (Figure 9B) [37]. The inhibition was complete at 80 and $100 \mu \mathrm{M}$ of dolastane diterpene on platelet aggregation induced by ADP and induced by collagen, respectively, with an $\mathrm{IC}_{50}$ around $35 \mu \mathrm{M}$ for both inducers [37]. Concerning the coagulation effects, dolastane also inhibited coagulation induced by thrombin, in a concentration-dependent manner. At a concentration of $90 \mu \mathrm{M}$, dolastane inhibited $95 \%$ of coagulation in human plasma $\left(\mathrm{IC}_{50}\right.$ of $\left.25 \mu \mathrm{M}\right)$ and $64 \%$ in bovine fibrinogen $\left(\mathrm{IC}_{50}\right.$ of $45 \mu \mathrm{M})$ [37].

Dichotomanol and pachydictyol A/isopachydictyol, obtained in 2014 from the brown alga Dictyota menstrualis [148], were investigated for their effects on ADP- or collagen-induced aggregation of PRP and on collagen- or thrombin-induced aggregation of WP. Dichotomanol inhibited, in a concentration-dependent manner, ADP- or collagen-induced platelet aggregation in PRP, with $\mathrm{IC}_{50}$ values of $0.31 \mathrm{mM}$ and $1.06 \mathrm{mM}$, respectively (Figure 9B). However, when tested on WP, the inhibition was not sufficient to obtain an $\mathrm{IC}_{50}$ (at $0.32 \mathrm{mM}$ inhibited $15 \%$ and $30 \%$ aggregation induced by collagen or thrombin, respectively). In complete contrast, pachydictyol A/isopachydictyol inhibited aggregation induced by collagen or thrombin on WP with $\mathrm{IC}_{50}$ values of $0.12 \mathrm{mM}$ and $0.25 \mathrm{mM}$, respectively, while when tested on collagen- and ADP-induced aggregation in PRP inhibition, it was not sufficient to obtain an $\mathrm{IC}_{50}$ (at $1.38 \mathrm{mM}$ inhibited $15 \%$ and $20 \%$ aggregation induced by collagen or ADP, respectively) [148]. Tests with both PRP and WP are important to evaluate if any component of plasma will interfere with the effect of the tested compounds [148]. Concerning coagulation times, 
APTT, PT, and fibrinogen coagulation were evaluated. Dichotomanol, at a concentration of $1.3 \mathrm{mM}$, delayed the PT (41.0 s) and APTT (139.9 s) coagulation tests, while pachydictyol A/isopachydictyol $\mathrm{A}$, at $1.4 \mathrm{mM}$, only delayed the APTT (87.6 s) coagulation test. The diterpenes, dichotomanol, and pachydictyol A/isopachydictyol A inhibited the coagulation of fibrinogen induced by thrombin in $86.4 \mathrm{~s}$ and $66.7 \mathrm{~s}$, respectively [148].

\subsubsection{Alkaloids}

Marine alkaloids have already provided valuable drugs to the market, such as the marine antineoplastic alkaloid, trabectedin (ET-743, Yondelis ${ }^{\circledR}$ ) [149], and are a fruitful source of bioactive compounds. Concerning antithrombotic activity, zoanthamine-type alkaloids showed promising antiplatelet activities. In vitro biological assays of seven zoanthamine-type alkaloids (Figure 12), isolated in 2003 from marine zoanthids belonging to the Zoanthus genus, were performed, focusing on human platelet aggregation induced by several stimulating agents, namely thrombin, collagen, or arachidonic acid (AA) [150].

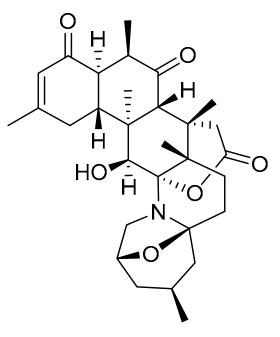

11-Hydroxyzoanthamine

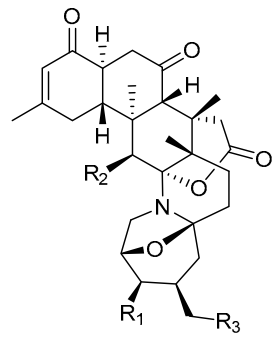

3-Hydroxynorzoanthamine $\mathrm{R}_{1}=\mathrm{OH}, \mathrm{R}_{2}=\mathrm{H}, \mathrm{R}_{3}=\mathrm{H}$ 11-Hydroxynorzoanthamine $\mathrm{R}_{1}=\mathrm{H}, \mathrm{R}_{2}=\mathrm{OH}, \mathrm{R}_{3}=\mathrm{H}$ 30-Hydroxynorzoanthamine $\mathrm{R}_{1}=\mathrm{H}, \mathrm{R}_{2}=\mathrm{H}, \mathrm{R}_{3}=\mathrm{OH}$

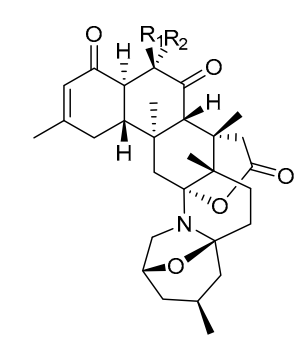

Oxyzoanthamine $\mathrm{R}_{1}=\mathrm{OH}, \mathrm{R}_{2}=\mathrm{H}$ Epioxyzoanthamine $\mathrm{R}_{1}=\mathrm{H}, \mathrm{R}_{2}=\mathrm{CH}_{2} \mathrm{OH}$

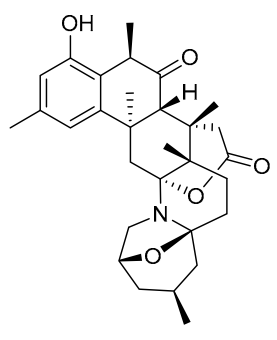

Zoanthenol

Figure 12. Chemical structures of zoanthamine-type alkaloids with antithrombotic activity.

11-Hydroxyzoanthamine strongly inhibited platelet aggregation induced by thrombin, collagen, and AA, with a percentage of inhibition of approximately $85 \%, 82 \%$, and $100 \%$, respectively, at $1 \mathrm{mM}$ (Figure 9B). On the other hand, at the same concentration, compounds 3-hydroxynorzoanthamine and 11-hydroxynorzoanthamine (Figure 12) exhibited a more selective effect towards the aggregation induced by collagen (approximately $85 \%$ and $100 \%$, respectively) and AA (approximately $82 \%$ and $100 \%$, respectively), in contrast to the effects obtained with thrombin-induced aggregation (approximately $25 \%$ and 50\%, respectively). 30-Hydroxynorzoanthamine also showed a more selective effect towards aggregation induced by collagen $(60 \%$ inhibition at $1 \mathrm{mM})$ and AA (35\% inhibition at $1 \mathrm{mM}$ ) but overall behaved as a less powerful antiplatelet agent. Another series of zoanthamines behaved as selective inhibitors of collagen-induced platelet aggregation, namely oxyzoanthamine (approximately $50 \%$ inhibition at $0.5 \mathrm{mM}$ ), zoanthenol (approximately $70 \%$ inhibition at $0.5 \mathrm{mM}$ ), and epioxyzoanthamine (approximately $14 \%$ inhibition at $0.5 \mathrm{mM}$ ), which cause little or no effect against AA- or thrombin-induced aggregation (Figure 9B) [150]. This pharmacological study demonstrates that small structural variations have a marked influence on the antithrombotic activity of zoanthamines [150].

\subsubsection{Polyphenols}

Five polyphenols isolated from different marine organisms were evaluated through different assays (Figure 13).

Eckol and dieckol, two purified phlorotannins, isolated from Eclonia kurome in 1985, exhibited fibrinolytic activity inhibiting the main plasmin inhibitors, $\alpha_{2}$-macroglubin $\left(\mathrm{IC}_{50}\right.$ of 2.5 and $5.0 \mu \mathrm{g} / \mathrm{mL}$, respectively) and $\alpha_{2}$-antiplasmin ( $\mathrm{IC}_{50}$ of 1.6 and $0.8 \mu \mathrm{g} / \mathrm{mL}$, respectively) [42]. In 2012, further tests were assayed, and eckol $(10 \mu \mathrm{M})$ and dieckol $(10 \mu \mathrm{M})$ [36] prolonged coagulation times in APTT (71.6 s and $82.5 \mathrm{~s}$, respectively) and in PT (26.9 s and $29.4 \mathrm{~s}$, respectively) tests weaker than HP 
(at $1.5 \mu \mathrm{g} / \mathrm{mL}$, the coagulation time was $>300 \mathrm{~s}$ in the APTT and $62.4 \mathrm{~s}$ in the PT assay). These effects suggested that eckol and dieckol are inhibitors of the common pathway and of the extrinsic pathway of coagulation (Figure 9A) [36]. The inhibitory effect on thrombin and FXa activities was also measured, in order to elucidate their anticoagulant mechanism action, in the absence or presence of ATIII. The two phlorotannins only inhibited the amidolytic activity of thrombin in the absence of ATIII (Figure 9A) [36]. The author justified the small differences between eckol and dieckol anticoagulant activity as being attributed to the different number and position of hydrogen donating hydroxyl groups in the molecules of these compounds [36].

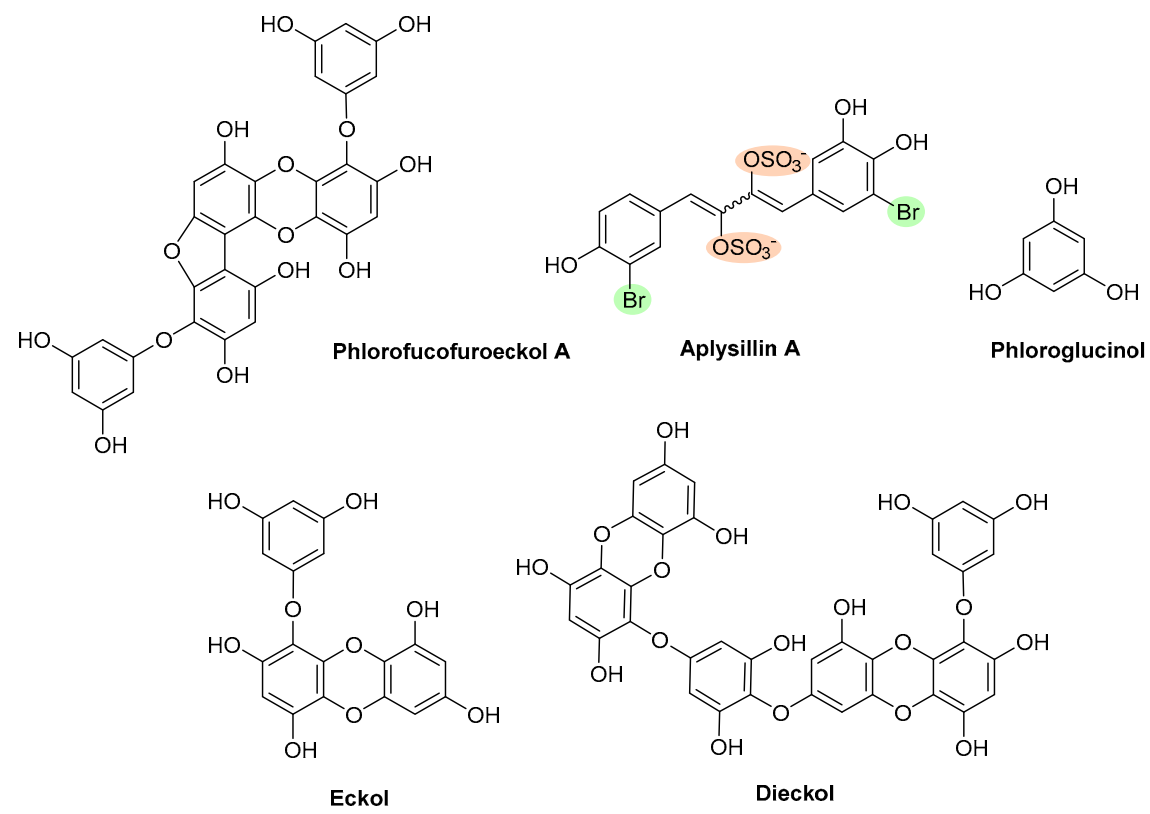

Figure 13. Chemical structures of polyphenols with antithrombotic activity.

Phlorofucofuroeckol A, a phlorotannin isolated in 1990 from the brown alga Ecklonia kurome, showed fibrinolytic activity in plasma by inhibition of the main plasmin inhibitors, $\alpha_{2}$-macroglubin and $\alpha_{2}$-antiplasmin, with $\mathrm{IC}_{50}$ values of $1.0 \mu \mathrm{g} / \mathrm{mL}$ and $0.3 \mu \mathrm{g} / \mathrm{mL}$, respectively [43].

Aplysillin A, a disulfated and dibrominated 1,4-diphenyl-1,3-butadiene, was isolated in 1995 from the sponge Aplysina fistularis fulva (Pallas) and was able to inhibit the binding of thrombin to platelet membranes with an $\mathrm{IC}_{50}$ value of $20 \mu \mathrm{M}$ (Figure 9B) [151].

Phloroglucinol, a common monomer unit of the polymer phlorotannin, was found in Ecklonia species in 1997 [152]. Phloroglucinol $(10 \mu \mathrm{M})$ prolonged coagulation times to $93.1 \mathrm{~s}$ and $34.1 \mathrm{~s}$ in the APTT and PT tests, respectively, comparing with the control (35.2 s on APTT and 17.2 s on PT). Although weaker than HP (at $1.5 \mu \mathrm{g} / \mathrm{mL}$ APTT $>300 \mathrm{~s}$ and PT $62.4 \mathrm{~s}$ ), the prolongation of APTT and prolongation of PT by phloroglucinol suggested the inhibition of the common pathway and inhibition of extrinsic pathway of coagulation, respectively [39]. The inhibitory effect on thrombin and FXa activities was measured to elucidate the anticoagulant mechanism of the phloroglucinol, in the absence or presence of ATIII. Phloroglucinol inhibited the amidolytic activity of thrombin, in the absence of ATIII, in a dose-dependent manner. However, in the presence of ATIII, no inhibition was observed [39], leading to the hypothesis that phloroglucinol anticoagulant activity was due to direct inhibition of thrombin activity. Phloroglucinol also showed a direct inhibitory effect on FXa activity, in the absence of ATIII, and no effect was observed in the presence of ATIII (Figure 9A) [39]. In 2012, further studies concerning antiplatelet aggregation showed that phloroglucinol $(2.5-25 \mu \mathrm{M})$ inhibited AA-induced platelet aggregation in a concentration dependent manner. Phloroglucinol $(10,25$, and $50 \mu \mathrm{M})$ also inhibited cyclooxygenase (COX) 1 enzyme activity by $45 \%, 64 \%$, and $74 \%$, respectively, and COX-2 by $49 \%, 53 \%$, and $72 \%$, respectively. In vivo bleeding time in mice was significantly prolonged by 
phloroglucinol (maximal bleeding time approximately $180 \mathrm{~s}$, at $0.5 \mu \mathrm{M} /$ mice), compared to the control mice that had an average tail bleeding time of $84 \mathrm{~s}$ (Figure 9A,B) [153].

A combination of thrombin and FXa inhibitory activities in a single, synthetic, orally active compound with low molecular weight is a promising approach to antithrombotic therapy [11]. In fact, a study found synergistic effects in the simultaneous inhibition of thrombin and FXa, in a rabbit arteriovenous shunt model of thrombosis [154]. Dual-acting thrombin/FXa inhibitors were already developed by Boehringer Ingelheim [155] and also by Merck \& Co pharmaceutical companies [156].

\subsubsection{Steroids}

Four steroids isolated in 1996 from sponges were investigated for their antiplatelet actions (Figure 14). Contignasterol, isolated from the marine sponge Petrosia contignata, exhibited inhibitory activity against platelet aggregation induced by PAF and also induced by collagen. The inhibition of platelet aggregation was found to be complete when induced by PAF (at $50 \mu \mathrm{g} / \mathrm{mL}$ ) and collagen (at $20 \mu \mathrm{g} / \mathrm{mL}$ ) (Figure 9B) [157].

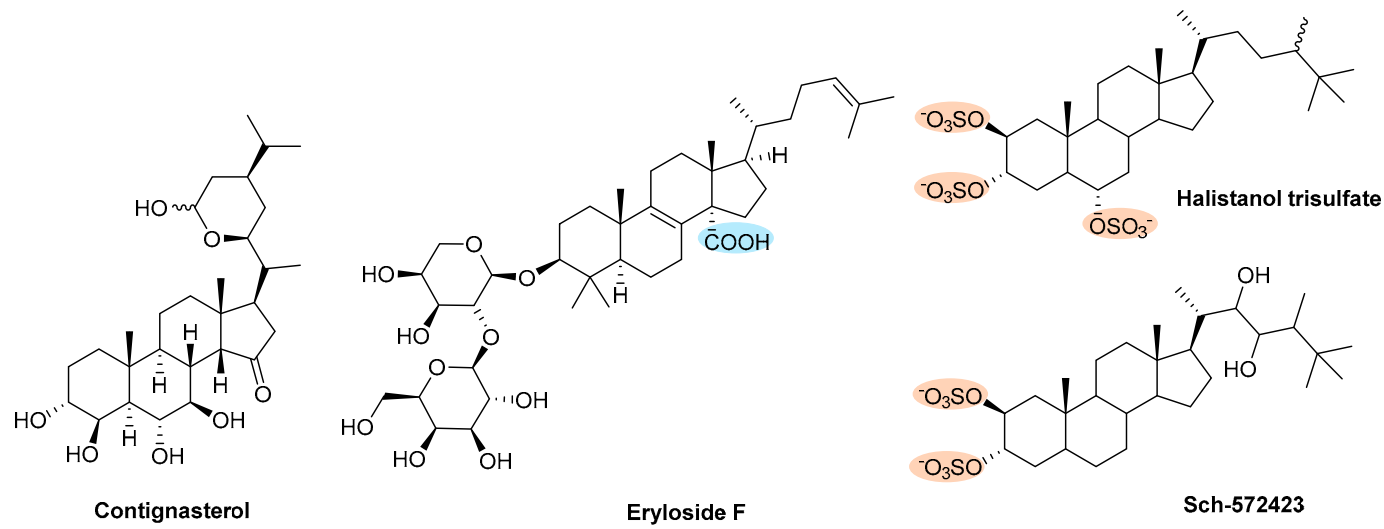

Figure 14. Chemical structures of steroids with antithrombotic activity.

Eryloside F, a disaccharide of the steroidal carboxylic acid penasterol obtained in 2000 from marine sponge Erylus formosus, exhibited functional activity in an in vitro human WP aggregation assay [158]. Eryloside $\mathrm{F}$ was able to inhibit the platelet aggregation induced by a thrombin receptor activating peptide, SFLLRN, and a stable thromboxane A2 mimetic, U-46619 with $\mathrm{IC}_{50}$ values of 0.3 and $1.7 \mathrm{mg} / \mathrm{mL}$, respectively. Eryloside F was also tested against platelet aggregation induced by thrombin, but potency was to low relative to its potency against SFLLRN-induced platelet aggregation [158].

In 2003, two sulfated sterols were isolated from the marine sponge Topsentia sp. (Halichondriidae), the halistanol trisulfate and the Sch-572423, which were identified as antiplatelet agents acting through $\mathrm{P}^{2} \mathrm{Y}_{12}$ receptors (Figure $9 \mathrm{~B}$ ) with $\mathrm{IC}_{50}$ values of 0.48 and $2.2 \mu \mathrm{M}$, respectively [159]. P2 $\mathrm{Y}_{12}$ is one of the most important ADP receptors and is the target of ticlopidine, clopidogrel, prasugrel, ticagrelor, and cangrelor [160].

\subsubsection{Polyketides}

Three polyketides were isolated from different species of marine sponges and tested for their antiplatelet activity (Figure 15).

Okadaic acid, a polyether derivative of a $\mathrm{C}_{38}$-fatty acid, originally isolated from the marine sponges of the genus Halichondria okadai in 1981 [161], is a marine sponge toxin that inhibits thrombin-induced aggregation of rabbit platelets [162] and was identified as a potent inhibitor of protein phosphatases type 1 and type 2A [163]. Okadaic acid inhibited thrombin-induced aggregation, ATP release, and the increase in cellular $\mathrm{Ca}^{2+}$ induced by thrombin in $8.1 \%, 17.2 \%$, and $20.7 \%$, respectively, at a concentration of $1 \mu \mathrm{M}$ [162]. 
Table 2. Antithrombotic activities of peptides, terpenes, alkaloids, polyphenols, steroids, and polyketides isolated from marine sources.

\begin{tabular}{|c|c|c|c|c|c|c|}
\hline \multirow{2}{*}{$\begin{array}{l}\text { Chemical } \\
\text { Class }\end{array}$} & \multirow{2}{*}{ Name } & \multirow{2}{*}{ Source } & \multirow{2}{*}{ Structure } & \multicolumn{2}{|l|}{ Antithrombotic Assays } & \multirow{2}{*}{ Ref. } \\
\hline & & & & Anticoagulant & Antiplatelet & \\
\hline \multirow{8}{*}{ Peptides } & $\begin{array}{l}\text { Peptide from seaweed } \\
\text { Porphyra yezoensis }\end{array}$ & Seaweed (Porphyra yezoensis) & NR & $\uparrow \mathrm{APTT}$ & NT & [142] \\
\hline & Plancinin & Starfish (Acanthaster planci) & NR & $\begin{array}{l}\uparrow \text { Fibrin test } \\
\uparrow \text { APTT and PT } \\
\Theta \text { Prothrombinase complex } \\
\uparrow \text { Bleeding time (in vivo) }\end{array}$ & NA & [140] \\
\hline & Dysinosin A-D & Sponge (Dysideidae) & Figure 10 & $\Theta$ FVIIa, thrombin & NT & {$[38,141]$} \\
\hline & UAP & Echiuroid worm (U. unicinctus) & NR & $\begin{array}{l}\uparrow \text { APTT } \\
\text { Binds to FIXa }\end{array}$ & NT & [33] \\
\hline & MEAP & Blue mussel (Mytilus edulis) & NR & $\begin{array}{l}\uparrow \text { APTT and TT } \\
\Theta \text { Amidolytic activation of FX } \\
\uparrow \text { Catalytic conversion of prothrombin } \\
\text { to thrombin }\end{array}$ & NT & [35] \\
\hline & $\begin{array}{l}\text { Protein from blood ark } \\
\text { shell }\end{array}$ & $\begin{array}{l}\text { Blood ark shell (Scapharca } \\
\text { broughtonii) }\end{array}$ & NR & $\begin{array}{l}\uparrow \text { APTT } \\
\Theta \text { FIX }\end{array}$ & NT & {$[41]$} \\
\hline & YAP & Yellowfin sole (Limanda aspera) & NR & $\begin{array}{l}\uparrow \text { APTT } \\
\Theta \text { FXIIa }\end{array}$ & $\begin{array}{l}\Theta \text { Thrombin- or ADP-induced } \\
\text { aggregation }\end{array}$ & [40] \\
\hline & TGAP & Granulated ark (T. granosa) & NR & $\begin{array}{l}\uparrow \mathrm{TT} \\
\Theta \mathrm{FVa} \\
\Theta \text { Interaction between prothrombin } \\
\text { and FVa }\end{array}$ & NT & [165] \\
\hline \multirow{5}{*}{ Terpenes } & Halisulfate and Suvanine & $\begin{array}{l}\text { Sponge } \\
\text { (Coscinoderma mathewsi) }\end{array}$ & \multirow{5}{*}{ Figure 11} & $\Theta$ Thrombin and trypsin & NT & [145] \\
\hline & SHQA and SQA & $\begin{array}{l}\text { Algae (Sargassum micranthum } \\
\text { and Sargassum yezoense) }\end{array}$ & & $\begin{array}{l}\text { Fast recovery time from paralysis } \\
\text { (in vivo) }\end{array}$ & $\Theta$ Collagen-induced aggregation & {$[146,147]$} \\
\hline & Dolastane & $\begin{array}{l}\text { Brown algae } \\
\text { (Canistrocarpus cervicornis) }\end{array}$ & & $\Theta$ Thrombin-induced coagulation & $\begin{array}{l}\Theta \text { ADP- or collagen-induced } \\
\text { aggregation }\end{array}$ & [37] \\
\hline & Dichotomanol & $\begin{array}{l}\text { Brown algae } \\
\text { (Dictyota menstrualis) }\end{array}$ & & $\begin{array}{l}\uparrow \text { APTT and PT } \\
\Theta \text { Thrombin-induced fibrinogen }\end{array}$ & $\begin{array}{l}\Theta \text { ADP- or collagen-induced } \\
\text { aggregation }\end{array}$ & [148] \\
\hline & $\begin{array}{l}\text { Pachydictyol } \\
\text { A/Isopachydictyol }\end{array}$ & $\begin{array}{l}\text { Brown algae } \\
\text { (Dictyota menstrualis) }\end{array}$ & & $\begin{array}{l}\uparrow \text { APTT } \\
\Theta \text { Thrombin-induced fibrinogen }\end{array}$ & $\begin{array}{l}\Theta \text { ADP- or thrombin-induced } \\
\text { aggregation }\end{array}$ & [148] \\
\hline
\end{tabular}


Table 2. Cont.

\begin{tabular}{|c|c|c|c|c|c|c|}
\hline \multirow{2}{*}{$\begin{array}{l}\text { Chemical } \\
\text { Class }\end{array}$} & \multirow{2}{*}{ Name } & \multirow{2}{*}{ Source } & \multirow{2}{*}{ Structure } & \multicolumn{2}{|l|}{ Antithrombotic Assays } & \multirow{2}{*}{ Ref. } \\
\hline & & & & Anticoagulant & Antiplatelet & \\
\hline \multirow{3}{*}{ Alkaloids } & 11-Hydroxyzoanthamine & \multirow{3}{*}{$\begin{array}{l}\text { Zoanthids (Zoanthus Z. } \\
\text { nymphaeus and an unidentified } \\
\text { species of Zoanthus sp.) }\end{array}$} & \multirow{3}{*}{ Figure 10} & NT & $\begin{array}{l}\Theta \text { Thrombin-, collagen- or } \\
\text { AA-induced aggregation }\end{array}$ & [150] \\
\hline & $\begin{array}{l}3 \text { and } \\
\text { 11-Hydroxynorzoanthamine }\end{array}$ & & & NT & $\begin{array}{l}\Theta \text { Collagen- or AA-induced } \\
\text { aggregation }\end{array}$ & [150] \\
\hline & $\begin{array}{l}\text { Oxyzoanthamine, } \\
\text { Zoethenol and } \\
\text { Epioxyzoanthamine }\end{array}$ & & & NT & $\Theta$ Collagen-induced aggregation & [150] \\
\hline \multirow{4}{*}{ Polyphenols } & Phlorofucofuroeckol A & Brown algae (Ecklonia Kurome) & \multirow{4}{*}{ Figure 13} & $\Theta$ Plasmin inhibitors & NT & [43] \\
\hline & Aplysillin A & $\begin{array}{l}\text { Sponge (Aplysina } \\
\text { fistularis fulva) }\end{array}$ & & $\Theta$ Thrombin to platelet membranes & NT & [151] \\
\hline & Phloroglucinol & Brown algae (Ecklonia species) & & $\begin{array}{l}\uparrow \text { APTT and PT } \\
\Theta \text { Amidolytic activity of thrombin, in } \\
\text { the absence of ATIII } \\
\Theta \text { FXa in the absence of ATIII } \\
\uparrow \text { Bleeding time (in vivo) }\end{array}$ & $\begin{array}{l}\Theta \text { AA-induced aggregation } \\
\Theta \text { COX-1 enzyme }\end{array}$ & {$[152,153]$} \\
\hline & Eckol and Dieckol & Brown algae (Ecklonia kurome) & & $\begin{array}{l}\uparrow \text { APTT and PT } \\
\Theta \text { Amidolytic activity of thrombin, in } \\
\text { the absence of ATIII } \\
\Theta \text { FXa in the absence of ATIII } \\
\Theta \text { Plasmin inhibitors }\end{array}$ & NT & [36] \\
\hline \multirow{3}{*}{ Steroids } & Contignasterol & Sponge (Petrosia contignata) & \multirow{3}{*}{ Figure 14} & NT & $\begin{array}{l}\Theta \text { PAF- or collagen-induced } \\
\text { aggregation }\end{array}$ & [156] \\
\hline & Eryloside F & Sponge (Erylus formosus) & & NT & $\begin{array}{l}\Theta \text { SFLLRN and U-46619 induced } \\
\text { aggregation }\end{array}$ & [158] \\
\hline & $\begin{array}{l}\text { Halistanol trisulfate and } \\
\text { Sch-572423 }\end{array}$ & Sponge (Topsentia sp.) & & NT & $\begin{array}{l}\Theta \text { Platelet aggregation acting } \\
\text { through } \mathrm{P}_{12} \mathrm{Y}_{12} \text { receptors }\end{array}$ & [159] \\
\hline \multirow[t]{2}{*}{ Polyketides } & Okadaic acid & Sponges (Halichondria okadai) & \multirow[t]{2}{*}{ Figure 15} & NT & $\begin{array}{l}\Theta \text { Thrombin-induced aggregation } \\
\Theta \text { Protein phosphatases type } 1 \text { and } \\
\text { type } 2 \mathrm{~A} \\
\Theta \text { ATP release and increased } \\
\text { cellular } \mathrm{Ca}^{2+}\end{array}$ & [162] \\
\hline & $\begin{array}{l}\text { Xestospongin/Araguspongine } \\
\text { and } \\
\text { 5,6-Dibromotryptamine }\end{array}$ & Sponge (Xestospongia sp.) & & NT & $\begin{array}{l}\Theta \text { Collagen- or } \\
\text { epinephrine-induced aggregation }\end{array}$ & [164] \\
\hline
\end{tabular}

$\uparrow —$ prolonged/delayed $\Theta$-inhibitor; SFLLRN—thrombin receptor activating peptide; U-46619—stable thromboxane A2 mimetic; NR—not represented; NT—not tested; NA—not active. 


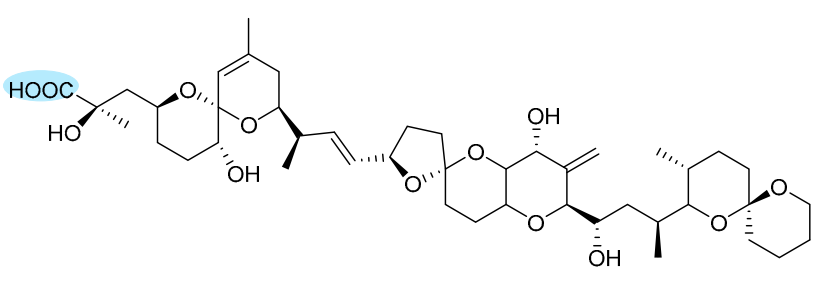

Okadaic acid

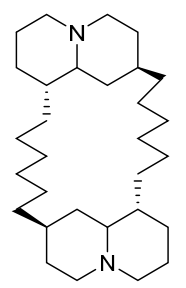

Xestospongin araguspongine

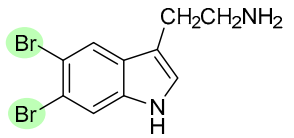

5,6-dibromotryptamine

Figure 15. Chemical structures of polyketides with antithrombotic activity.

Xestospongin/araguspongine, isolated in 2003 from the marine sponge Xestospongia sp., inhibited collagen-induced aggregation and epinephrine-induced aggregation by $91.6 \%$ at $200 \mu \mathrm{g} / \mathrm{mL}$ and by $97.4 \%$ at $200 \mu \mathrm{g} / \mathrm{mL}$, respectively, while 5,6-dibromotryptamine, from the sponge Aplysina sp., inhibited collagen- and epinephrine-induced aggregation by $77.8 \%$ at $200 \mu \mathrm{g} / \mathrm{mL}$ and by $92.0 \%$ at $200 \mu \mathrm{g} / \mathrm{mL}$ [164].

\section{Conclusions}

Cardiovascular diseases are a leading contributor to morbidity and mortality in the 21st century. Demand for new antithrombotic compounds, especially with multitarget actions, is increasing. Oceans constitute a vast source of structurally new and unique biologically active molecules, being a rich source of diverse organisms, containing thousands of described species and many others yet to be discovered. The lower contamination levels of viruses and/or prions in marine organisms in comparison with the risks associated with mammalian HP derivatives is a strength of this source of potential antithrombotic molecules.

Polysaccharides constitute one of the most studied molecules as potential antithrombotic agents; however, oral bioavailability could be an issue, as it happens with HP. Exploring other chemical classes with smaller and/ or different structures could be an advantage in discovering compounds that are potentially orally active.

Herein, 38 non-polysaccharide compounds were presented, from six different chemical classes, such as alkaloids, peptides, polyketides, polyphenols, steroids, and terpenes, with very unique structures and high degrees of molecular substitution, which were studied for their anticoagulant and/or antiplatelet activities in different assays. The majority of these marine antithrombotic compounds were isolated from sponges or algae, with the exception of the antithrombotic peptides, which were extracted from a large diversity of marine species, such as sponges, starfish, bivalves, fish, and marine worms. The antithrombotic activity of more than half of these molecules was described after the year 2000, in which half was described in the last decade. Many marine compounds were studied through both in vitro and in vivo assays.

Several compounds exhibited dual activity, which is an attractive approach in complex etiologies, such as cardiovascular diseases. The combination of an anticoagulant with an antiplatelet drug has already proven its benefits on antithrombotic therapy for patients with acute arterial thrombosis. Three terpenes (dichotomanol, dolastane diterpene, and pachydictyol), one protein (YAP), and one polyphenol (phloroglucinol) exhibited dual anticoagulant and antiplatelet activities. This profile was also found in some polysaccharides (FCS, MM, and E.l.). Additionally, dual anticoagulant activity through direct inhibition of serine proteases was exhibited by peptides dysinosins A-C (FVIIa and thrombin) as also by the polyphenols phloroglucinol, eckol, and dieckol (FXa and thrombin). These three serine proteases are crucial coagulation factors and have been pointed out as preferred targets for the development of new antithrombotic drugs.

This review highlights the new scaffolds being disclosed as promising antithrombotic agents and the opportunity of testing novel classes beyond the polysaccharide chemical space. Further studies should be conducted in order to optimize these marine compounds by structural modifications, as well 
as to better understand their structure-antithrombotic activity relationship in order to develop new solutions for cardiovascular diseases.

\section{Future of Marine Antithrombotic Molecules}

The methods to determine antithrombotic activity are evolving along with the advances of clinical and pharmaceutical analysis. Nevertheless, the majority of the reports presented herein limited their studies to classical clotting assays and conventional coagulation targets. The intervention of the genomic/proteomic era in the investigation of antithrombotics from the sea is still to come. An increase in the studies of molecules from the sea was noted in the last decade, particularly for SGs and fucoidans polysaccharides and for novel frameworks. It is worth noting that MSP from the edible green algae is forthcoming as drug or as a food supplement for human health. Continuous efforts in this field will lead to developments of alga-derived agents with potential clinical uses in thrombosis. So far, the investigation on anticoagulant sulfated rhamnans is still less active than that of galactans and fucoidans, but if more efforts are made, more anticoagulant properties on the sulfated rhamnans should be obtained. Recent studies on polysaccharides highlight the importance of the molecular weight on their antithrombotic activities. Curiously, when observing the most active compounds from other frameworks, most are out of the space of the Lipinski rules and can be a limitation when aiming for oral bioavailability. Nonetheless, knowledge of peptidomimetic chemistry has increased in the last years, and tuning a peptide into a small orally-active molecule is a feasible project. The strength of these novel antithrombotic scaffolds is the high selectivity found in some representatives like the anticoagulant peptides UAP, MEAP, and the protein from the blood ark shell. Therefore, our bet for the future lies in these novel structures that can be the target of medicinal chemists to achieve the desirable bioavailability. One cannot discharge the multitarget compounds; this would be also the case for HP, which already rendered derivatives with different applications. In these complex etiologies, such as cardiovascular diseases, multitarget molecules have proven benefits. Most importantly, one needs to rule out or prove whether polyphenols, like the multitarget phloroglucinol, are not acting as PAINs (pan-assay interference compounds) through an unspecific mechanism of action functioning as reactive chemicals rather than discriminating drugs.

Author Contributions: The manuscript was conceived by E.S. and M.C.-d.-S.; F.C., R.R.C., and D.I.S.P.R. collected the primary data and compiled draft manuscripts; E.S., M.C.-d.-S., and M.M.M.P. supervised the development of the manuscript; all the authors assisted in data interpretation, manuscript evaluation, and editing.

Funding: This work was supported through project No. POCI-01-0145-FEDER-028736, co-financed by COMPETE 2020, Portugal 2020 and the European Union through the ERDF, and by FCT through national funds.

Conflicts of Interest: The authors declare no conflict of interest.

\section{Abbreviation List}

2APTT-Two-fold delay of cloth formation

AA-Arachidonic acid

ADP-Adenosine diphosphate

APTT-Activated partial thromboplastin time

AT-Antithrombin III

CS-Chondroitin sulfate

COX-Cyclooxygenase

DS-Dermatan sulfate

E.l.-Sulfated galactan from Echinometra lucunter

$\mathrm{F}$-Clotting factor

\author{
HsG-Fucosylated chondroitin sulfate from \\ Holothuria scabra \\ $\mathrm{IC}_{50}$ - Half maximal inhibitory concentration \\ IdoA-Iduronic acid \\ IdoA2S-2-Sulfated iduronic acid \\ KS-Keratan sulfate \\ LMW-Low molecular weight \\ LMWH_Low molecular weight heparin \\ L.v.-Sulfated fucan from Lytechinus variegatus \\ MEAP-M. edulis anticoagulant peptide \\ MM-Fucosylated chondroitin sulfate from \\ Massinium magnum
}


Fa-Activated clotting factor

FCS-Fucosylated chondroitin sulfate

FCSc_-Fucosylated chondroitin sulfate from Cucumaria frondosa

FCShm-Fucosylated chondroitin sulfate from Holothuria Mexicana

FCSt-Fucosylated chondroitin sulfate from

Thelenota ananas

Fcup-Fucopyranose

FHC-Fucogalactan from Hormophysa cuneiformis

FS-Sulfated fucan from Holothuria albiventer

FSA-Fucoidan from Sargassum aquifolium

FXase-factor Xase complex

GAGs-Glycosaminoglycans

Gal6S-6-Sulfated galactose

GalNAc4S-4-Sulfated N-acetylgalactosamine

GlcA-Glucuronic acid

GlcN-Glucosamine

GlcNAc-N-Acetylglucosamine

GlcNAc6S-6-Sulfated $N$-acetylglucosamine

GlcNS6S-N,6-Disulfated glucosamine

GP-Sulfated polysaccharide from Grateloupia livida

HP-Heparin

HS-Heparan sulfate
MSP-Sulfated polysaccharide from Monostroma angicava

PAF-Platelet activating factor

PAGE-Polyacrylamide gel electrophoresis

PAI-1 or -2-Plasminogen activator inhibitor 1 or 2

PRP-Platelet-rich plasma

PS-Polysaccharides

PT-Prothrombin time

S.f.-Sulfated fucan from Strongylocentrotus franciscanus

SFs-Sulfated fucans

SGs-Sulfated galactans

SHQA-Sargahydroquinoic acid

SPS-CF-Ulvan from Capsosiphon fulvescens

SQA-Sargaquinoic acid

TGAP_-Tegillarca granosa anticoagulant protein

TT-Thrombin time

TXA2-Thromboxane A2

$\mathrm{UAP}-$ Urechis unicinctus anticoagulant peptide

$\mathrm{u}-/ \mathrm{t}-\mathrm{PA}$-Tissue-type plasminogen activator

UFH-Unfractionated heparin

WP-Washed platelets

YAP-Yellowfin sole anticoagulant protein

\section{References}

1. World Health Organization. The Top 10 Causes of Death. Available online: https://www.who.int/newsroom/fact-sheets / detail/the-top-10-causes-of-death (accessed on 22 January 2019).

2. World Heath Organization. Cardiovascular Diseases (cvds). Available online: https://www.who.int/newsroom/fact-sheets/detail/ cardiovascular-diseases-(cvds) (accessed on 22 January 2019).

3. Oduah, E.I.; Linhardt, R.J.; Sharfstein, S.T. Heparin: Past, present, and future. Pharmaceuticals 2016, 9, 38. [CrossRef] [PubMed]

4. Ralf, J.L. Therapeutic use of heparin beyond anticoagulation. Curr. Drug Discov. Technol. 2009, 6, 281-289. [CrossRef]

5. Varki, N.M.; Varki, A. Heparin inhibition of selectin-mediated interactions during the hematogenous phase of carcinoma metastasis: Rationale for clinical studies in humans. Semin. Thromb. Hemost. 2002, 28, 53-66. [CrossRef]

6. Wang, L.; Brown, J.R.; Varki, A.; Esko, J.D. Heparin's anti-inflammatory effects require glucosamine 6-o-sulfation and are mediated by blockade of 1- and p-selectins. J. Clin. Investig. 2002, 110, 127-136. [CrossRef] [PubMed]

7. Neves, A.R.; Correia-da-Silva, M.; Sousa, E.; Pinto, M. Strategies to overcome heparins' low oral bioavailability. Pharmaceuticals 2016, 9, 37. [CrossRef] [PubMed]

8. Martins, A.; Vieira, H.; Gaspar, H.; Santos, S. Marketed marine natural products in the pharmaceutical and cosmeceutical industries: Tips for success. Mar. Drugs 2014, 12, 1066-1101. [CrossRef] [PubMed]

9. Vasconcelos, A.A.; Pomin, V.H. Marine carbohydrate-based compounds with medicinal properties. Mar. Drugs 2018, 16, 233. [CrossRef]

10. Khotimchenko, Y. Pharmacological potential of sea cucumbers. Int. J. Mol. Sci. 2018, 19, 1342. [CrossRef]

11. Neves, A.R.; Correia-da-Silva, M.; Sousa, E.; Pinto, M. Structure-activity relationship studies for multitarget antithrombotic drugs. Future Med. Chem. 2016, 8, 2305-2355. [CrossRef]

12. Cunha, L.; Grenha, A. Sulfated seaweed polysaccharides as multifunctional materials in drug delivery applications. Mar. Drugs 2016, 14, 42. [CrossRef]

13. Pomin, V.H. Marine non-glycosaminoglycan sulfated glycans as potential pharmaceuticals. Pharmaceuticals 2015, 8, 848-864. [CrossRef] [PubMed] 
14. Mourao, P.A. Perspective on the use of sulfated polysaccharides from marine organisms as a source of new antithrombotic drugs. Mar. Drugs 2015, 13, 2770-2784. [CrossRef] [PubMed]

15. Kang, H.K.; Seo, C.H.; Park, Y. The effects of marine carbohydrates and glycosylated compounds on human health. Int. J. Mol. Sci. 2015, 16, 6018-6056. [CrossRef]

16. Ustyuzhanina Nadezhda, E.; Ushakova Natalia, A.; Preobrazhenskaya Marina, E.; Bilan Maria, I.; Tsvetkova Eugenia, A.; Krylov Vadim, B.; Anisimova Natalia, A.; Kiselevskiy Mikhail, V.; Krukovskaya Nadezhda, V.; Li, C.; et al. Fucoidans as a platform for new anticoagulant drugs discovery. Pure Appl. Chem. 2014, 86, 1365. [CrossRef]

17. Pomin, V.H. Anticoagulant motifs of marine sulfated glycans. Glycoconj. J. 2014, 31, 341-344. [CrossRef] [PubMed]

18. Nasri, R.; Nasri, M. Marine-derived bioactive peptides as new anticoagulant agents: A review. Curr. Protein Pept. Sci. 2013, 14, 199-204. [CrossRef] [PubMed]

19. Pomin, V.H.; Mourão, P.A.d.S. Structure versus anticoagulant and antithrombotic actions of marine sulfated polysaccharides. Rev. Bras. Farmacogn. 2012, 22, 921-928. [CrossRef]

20. Misurcova, L.; Skrovankova, S.; Samek, D.; Ambrozova, J.; Machu, L. Health benefits of algal polysaccharides in human nutrition. Adv. Food Nutr. Res. 2012, 66, 75-145. [CrossRef] [PubMed]

21. Jiao, G.; Yu, G.; Zhang, J.; Ewart, H.S. Chemical structures and bioactivities of sulfated polysaccharides from marine algae. Mar. Drugs 2011, 9, 196-223. [CrossRef]

22. Delattre, C.; Fenoradosoa, T.A.; Michaud, P. Galactans: An overview of their most important sourcing and applications as natural polysaccharides. Braz. Arch. Biol. Technol. 2011, 54, 1075-1092. [CrossRef]

23. Ale, M.T.; Mikkelsen, J.D.; Meyer, A.S. Important determinants for fucoidan bioactivity: A critical review of structure-function relations and extraction methods for fucose-containing sulfated polysaccharides from brown seaweeds. Mar. Drugs 2011, 9, 2106-2130. [CrossRef] [PubMed]

24. Pomin, V.H.; Mourao, P.A. Structure, biology, evolution, and medical importance of sulfated fucans and galactans. Glycobiology 2008, 18, 1016-1027. [CrossRef] [PubMed]

25. Kelly, M.S. Echinoderms: Their culture and bioactive compounds. Prog. Mol. Subcell. Biol. 2005, 39, $139-165$. [PubMed]

26. Vicente, C.P.; He, L.; Pavao, M.S.; Tollefsen, D.M. Antithrombotic activity of dermatan sulfate in heparin cofactor ii-deficient mice. Blood 2004, 104, 3965-3970. [CrossRef] [PubMed]

27. Mourao, P.A. Use of sulfated fucans as anticoagulant and antithrombotic agents: Future perspectives. Curr. Pharm. Des. 2004, 10, 967-981. [CrossRef] [PubMed]

28. Matsubara, K. Recent advances in marine algal anticoagulants. Curr. Med. Chem. Cardiovasc. Hematol. Agents 2004, 2, 13-19. [CrossRef] [PubMed]

29. Berteau, O.; Mulloy, B. Sulfated fucans, fresh perspectives: Structures, functions, and biological properties of sulfated fucans and an overview of enzymes active toward this class of polysaccharide. Glycobiology 2003, 13, 29r-40r. [CrossRef]

30. Shanmugam, M.; Mody, K.H. Heparinoid-active sulphated polysaccharides from marine algae as potential blood anticoagulant agents. Curr. Sci. 2000, 79, 1672-1683.

31. Pereira, M.S.; Mulloy, B.; Mourao, P.A. Structure and anticoagulant activity of sulfated fucans. Comparison between the regular, repetitive, and linear fucans from echinoderms with the more heterogeneous and branched polymers from brown algae. J. Biol. Chem. 1999, 274, 7656-7667. [CrossRef]

32. Kishore, K. In-vitro and in-vivo screening methods for antithrombotic agents. Am. J. Phytomed. Clin. Ther. 2013, 1, 497-506.

33. Jo, H.-Y.; Jung, W.-K.; Kim, S.-K. Purification and characterization of a novel anticoagulant peptide from marine echiuroid worm, urechis unicinctus. Process Biochem. 2008, 43, 179-184. [CrossRef]

34. Jung, W.K.; Jo, H.Y.; Qian, Z.J.; Jeong, Y.J.; Park, S.G.; Choi, I.W.; Kim, S.K. A novel anticoagulant protein with high affinity to blood coagulation factor va from tegillarca granosa. J. Biochem. Mol. Biol. 2007, 40, 832-838. [CrossRef] [PubMed]

35. Jung, W.-K.; Kim, S.-K. Isolation and characterisation of an anticoagulant oligopeptide from blue mussel, mytilus edulis. Food Chem. 2009, 117, 687-692. [CrossRef]

36. Kim, T.H.; Ku, S.K.; Bae, J.S. Antithrombotic and profibrinolytic activities of eckol and dieckol. J. Cell. Biochem. 2012, 113, 2877-2883. [CrossRef] [PubMed] 
37. de Andrade Moura, L.; Bianco, E.M.; Pereira, R.C.; Teixeira, V.L.; Fuly, A.L. Anticoagulation and antiplatelet effects of a dolastane diterpene isolated from the marine brown alga canistrocarpus cervicornis. J. Thromb. Thrombolysis 2011, 31, 235-240. [CrossRef]

38. Carroll, A.R.; Buchanan, M.S.; Edser, A.; Hyde, E.; Simpson, M.; Quinn, R.J. Dysinosins b-d, inhibitors of factor viia and thrombin from the australian sponge lamellodysidea c hlorea. J. Nat. Prod. 2004, 67, 1291-1294. [CrossRef] [PubMed]

39. Bae, J.-S. Antithrombotic and profibrinolytic activities of phloroglucinol. Food. Chem. Toxicol. 2011, 49, 1572-1577. [CrossRef]

40. Rajapakse, N.; Jung, W.-K.; Mendis, E.; Moon, S.-H.; Kim, S.-K. A novel anticoagulant purified from fish protein hydrolysate inhibits factor xiia and platelet aggregation. Life Sci. 2005, 76, 2607-2619. [CrossRef]

41. Jung, W.-K.; Je, J.-Y.; Kim, H.-J.; Kim, S.-K. A novel anticoagulant protein from scapharca broughtonii. J. Biochem. Mol. Biol. 2002, 35, 199-205. [CrossRef]

42. Yoshiyasu, F.; Iwao, M.; Ziunei, K.; Hideo, M.; Masaru, K.; Yasuo, N.; Masayuki, T.; Masamitsu, O. Eckols, novel phlorotannins with a dibenzo-p-dioxin skeleton possessing inhibitory effects on $\alpha 2$-macroglobulin from the brown alga ecklonia kurome okamura. Chem. Lett. 1985, 14, 739-742. [CrossRef]

43. Fukuyama, Y.; Kodama, M.; Miura, I.; Kinzyo, Z.; Mori, H.; Nakayama, Y.; Takahashi, M. Anti-plasmin inhibitor. Vi.: Structure of phlorofucofuroeckol a, a novel phlorotannin with both dibenzo-1, 4-dioxin and dibenzofuran elements, from ecklonia kurome okamura. Chem. Pharm. Bull. 1990, 38, 133-135. [CrossRef]

44. Liu, X.; Du, P.; Liu, X.; Cao, S.; Qin, L.; He, M.; He, X.; Mao, W. Anticoagulant properties of a green algal rhamnan-type sulfated polysaccharide and its low-molecular-weight fragments prepared by mild acid degradation. Mar. Drugs 2018, 16, 445. [CrossRef]

45. Park, B.-G.; Oh, S.; Kwon, D.; Cui, Y.; Ham, J.; Shin, W.-S.; Lee, S. Anti-platelet aggregation and anti-thrombotic effects of marine natural products sargahydroquinoic acid and sargaquinoic acid. Bull. Korean Chem. Soc. 2013, 34, 3121-3124. [CrossRef]

46. Koyama, T.; Noguchi, K.; Aniya, Y.; Sakanashi, M. Analysis for sites of anticoagulant action of plancinin, a new anticoagulant peptide isolated from the starfish acanthaster planci, in the blood coagulation cascade. Gen. Pharmacol. 1998, 31, 277-282. [CrossRef]

47. Vasconcelos, A.A.; Sucupira, I.D.; Guedes, A.L.; Queiroz, I.N.; Frattani, F.S.; Fonseca, R.J.; Pomin, V.H. Anticoagulant and antithrombotic properties of three structurally correlated sea urchin sulfated glycans and their low-molecular-weight derivatives. Mar. Drugs 2018, 16, 304. [CrossRef]

48. Ernst, B.; Magnani, J.L. From carbohydrate leads to glycomimetic drugs. Nat. Rev. Drug Discov. 2009, 8, 661-677. [CrossRef]

49. Zhang, F.; Zhang, Z.; Linhardt, R.J. Chapter 3-Glycosaminoglycans. In Handbook of Glycomics; Cummings, R.D., Pierce, J.M., Eds.; Academic Press: San Diego, CA, USA, 2010; pp. 59-80.

50. Vasconcelos, A.A.; Pomin, V.H. The sea as a rich source of structurally unique glycosaminoglycans and mimetics. Microorganisms 2017, 5, 51. [CrossRef]

51. Pomin, V.; Mourão, P. Specific sulfation and glycosylation-A structural combination for the anticoagulation of marine carbohydrates. Front. Cell. Infect. Microbiol. 2014, 4. [CrossRef]

52. Saravanan, R.; Shanmugam, A. Isolation and characterization of low molecular weight glycosaminoglycans from marine mollusc amussium pleuronectus (linne) using chromatography. Appl. Biochem. Biotechnol. 2010, 160, 791-799. [CrossRef]

53. Pavão, M.S.G.; Mourão, P.A.S.; Mulloy, B.; Tollefsen, D.M. A unique dermatan sulfate-like glycosaminoglycan from ascidian: Its structure and the effect of its unusual sulfation pattern on anticoagulant activity. J. Biol. Chem. 1995, 270, 31027-31036. [CrossRef]

54. Pavao, M.S.; Aiello, K.R.; Werneck, C.C.; Silva, L.C.; Valente, A.P.; Mulloy, B.; Colwell, N.S.; Tollefsen, D.M.; Mourao, P.A. Highly sulfated dermatan sulfates from ascidians. Structure versus anticoagulant activity of these glycosaminoglycans. J. Biol. Chem. 1998, 273, 27848-27857. [CrossRef]

55. Tapon-Bretaudière, J.; Chabut, D.; Zierer, M.; Matou, S.; Helley, D.; Bros, A.; Mourão, P.A.; Fischer, A.-M. A fucosylated chondroitin sulfate from echinoderm modulates in vitro fibroblast growth factor 2-dependent angiogenesis. Mol. Cancer Res. 2002, 1, 96-102. 
56. Santos, J.C.; Mesquita, J.M.; Belmiro, C.L.; da Silveira, C.B.; Viskov, C.; Mourier, P.A.; Pavão, M.S. Isolation and characterization of a heparin with low antithrombin activity from the body of styela plicata (chordata-tunicata). Distinct effects on venous and arterial models of thrombosis. Thromb. Res. 2007, 121, 213-223. [CrossRef]

57. Pavão, M.S.G. Structure and anticoagulant properties of sulfated glycosaminoglycans from primitive chordates. An. Acad. Bras. Ciênc. 2002, 74, 105-112. [CrossRef]

58. Vilela-Silva, A.-C.E.; Alves, A.-P.; Valente, A.-P.; Vacquier, V.D.; Mourão, P.A. Structure of the sulfated $\alpha$-l-fucan from the egg jelly coat of the sea urchin strongylocentrotus franciscanus: Patterns of preferential 2-o-and 4-o-sulfation determine sperm cell recognition. Glycobiology 1999, 9, 927-933. [CrossRef]

59. Pomin, V.H. Holothurian fucosylated chondroitin sulfate. Mar. Drugs 2014, 12, 232-254. [CrossRef]

60. Luo, L.; Wu, M.; Xu, L.; Lian, W.; Xiang, J.; Lu, F.; Gao, N.; Xiao, C.; Wang, S.; Zhao, J. Comparison of physicochemical characteristics and anticoagulant activities of polysaccharides from three sea cucumbers. Mar. Drugs 2013, 11, 399. [CrossRef]

61. Chen, S.; Xue, C.; Yin, L.a.; Tang, Q.; Yu, G.; Chai, W. Comparison of structures and anticoagulant activities of fucosylated chondroitin sulfates from different sea cucumbers. Carbohydr. Polym. 2011, 83, 688-696. [CrossRef]

62. Gomes, A.M.; Kozlowski, E.O.; Pomin, V.H.; de Barros, C.M.; Zaganeli, J.L.; Pavão, M.S. Unique extracellular matrix heparan sulfate from the bivalve nodipecten nodosus (linnaeus, 1758) safely inhibits arterial thrombosis after photochemically induced endothelial lesion. J. Biol. Chem. 2010, 285, 7312-7323. [CrossRef]

63. Brito, A.S.; Cavalcante, R.S.; Palhares, L.C.G.F.; Hughes, A.J.; Andrade, G.P.V.; Yates, E.A.; Nader, H.B.; Lima, M.A.; Chavante, S.F. A non-hemorrhagic hybrid heparin/heparan sulfate with anticoagulant potential. Carbohydr. Polym. 2014, 99, 372-378. [CrossRef]

64. Chavante, S.F.; Santos, E.A.; Oliveira, F.W.; Guerrini, M.; Torri, G.; Casu, B.; Dietrich, C.P.; Nader, H.B. A novel heparan sulphate with high degree of n-sulphation and high heparin cofactor-ii activity from the brine shrimp artemia franciscana. Int. J. Biol. Macromol. 2000, 27, 49-57. [CrossRef]

65. Liu, X.; Hao, J.; Shan, X.; Zhang, X.; Zhao, X.; Li, Q.; Wang, X.; Cai, C.; Li, G.; Yu, G. Antithrombotic activities of fucosylated chondroitin sulfates and their depolymerized fragments from two sea cucumbers. Carbohydr. Polym. 2016, 152, 343-350. [CrossRef]

66. Ustyuzhanina, N.E.; Bilan, M.I.; Dmitrenok, A.S.; Shashkov, A.S.; Kusaykin, M.I.; Stonik, V.A.; Nifantiev, N.E.; Usov, A.I. Structure and biological activity of a fucosylated chondroitin sulfate from the sea cucumber cucumaria japonica. Glycobiology 2016, 26, 449-459. [CrossRef]

67. Ustyuzhanina, N.E.; Bilan, M.I.; Dmitrenok, A.S.; Borodina, E.Y.; Stonik, V.A.; Nifantiev, N.E.; Usov, A.I. A highly regular fucosylated chondroitin sulfate from the sea cucumber massinium magnum: Structure and effects on coagulation. Carbohydr. Polym. 2017, 167, 20-26. [CrossRef]

68. Li, Q.; Cai, C.; Chang, Y.; Zhang, F.; Linhardt, R.J.; Xue, C.; Li, G.; Yu, G. A novel structural fucosylated chondroitin sulfate from holothuria mexicana and its effects on growth factors binding and anticoagulation. Carbohydr. Polym. 2018, 181, 1160-1168. [CrossRef]

69. Yang, L.; Wang, Y.; Yang, S.; Lv, Z. Separation, purification, structures and anticoagulant activities of fucosylated chondroitin sulfates from holothuria scabra. Int. J. Biol. Macromol. 2018, 108, 710-718. [CrossRef]

70. Fonseca, R.J.; Santos, G.R.; Mourao, P.A. Effects of polysaccharides enriched in 2,4-disulfated fucose units on coagulation, thrombosis and bleeding. Practical and conceptual implications. Thromb. Haemost. 2009, 102, 829-836. [CrossRef]

71. Arivuselvan, N.; Radhigaand, M.; Anantharaman, P. In vitro antioxidant and anticoagulant activities of sulphated polysaccharides from brown seaweed (turbinaria ornata) (turner) j. Agardh. Asian J. Pharm. Biol. Res. 2011, 232-239. [CrossRef]

72. Athukorala, Y.; Lee, K.W.; Kim, S.K.; Jeon, Y.J. Anticoagulant activity of marine green and brown algae collected from jeju island in korea. Bioresour. Technol. 2007, 98, 1711-1716. [CrossRef]

73. Azevedo, T.C.; Bezerra, M.E.; Santos Mda, G.; Souza, L.A.; Marques, C.T.; Benevides, N.M.; Leite, E.L. Heparinoids algal and their anticoagulant, hemorrhagic activities and platelet aggregation. Biomed. Pharmacother. 2009, 63, 477-483. [CrossRef]

74. Bilan, M.I.; Ustyuzhanina, N.E.; Shashkov, A.S.; Thanh, T.T.T.; Bui, M.L.; Tran, T.T.V.; Bui, V.N.; Nifantiev, N.E.; Usov, A.I. A sulfated galactofucan from the brown alga hormophysa cuneiformis (fucales, sargassaceae). Carbohydr. Res. 2018, 469, 48-54. [CrossRef] 
75. Chevolot, L.; Foucault, A.; Chaubet, F.; Kervarec, N.; Sinquin, C.; Fisher, A.-M.; Boisson-Vidal, C. Further data on the structure of brown seaweed fucans: Relationships with anticoagulant activity. Carbohydr. Res. 1999, 319, 154-165. [CrossRef]

76. de Andrade Moura, L.; Ortiz-Ramirez, F.; Cavalcanti, D.N.; Ribeiro, S.M.; Muricy, G.; Teixeira, V.L.; Fuly, A.L. Evaluation of marine brown algae and sponges from brazil as anticoagulant and antiplatelet products. Mar. Drugs 2011, 9, 1346-1358. [CrossRef]

77. Dobashi, K.; Nishino, T.; Fujihara, M.; Nagumo, T. Isolation and preliminary characterization of fucose-containing sulfated polysaccharides with blood-anticoagulant activity from the brown seaweed hizikia fusiforme. Carbohydr. Res. 1989, 194, 315-320. [CrossRef]

78. Dore, C.M.P.G.; Faustino Alves, M.G.d.C.; Pofírio Will, L.S.E.; Costa, T.G.; Sabry, D.A.; de Souza Rêgo, L.A.R.; Accardo, C.M.; Rocha, H.A.O.; Filgueira, L.G.A.; Leite, E.L. A sulfated polysaccharide, fucans, isolated from brown algae sargassum vulgare with anticoagulant, antithrombotic, antioxidant and anti-inflammatory effects. Carbohydr. Polym. 2013, 91, 467-475. [CrossRef]

79. Grauffel, V.; Kloareg, B.; Mabeau, S.; Durand, P.; Jozefonvicz, J. New natural polysaccharides with potent antithrombic activity: Fucans from brown algae. Biomaterials 1989, 10, 363-368. [CrossRef]

80. Karaki, N.; Sebaaly, C.; Chahine, N.; Faour, T.; Zinchenko, A.; Rachid, S.; Kanaan, H. The antioxidant and anticoagulant activities of polysaccharides isolated from the brown algae dictyopteris polypodioides growing on the lebanese coast. J. Appl. Pharm. Sci. 2013, 3, 43-51. [CrossRef]

81. Kuznetsova, T.; Besednova, N.; Mamaev, A.; Momot, A.; Shevchenko, N.; Zvyagintseva, T. Anticoagulant activity of fucoidan from brown algae fucus evanescens of the okhotsk sea. Bull. Exp. Biol. Med. 2003, 136, 471-473. [CrossRef]

82. Lee, S.-H.; Jeon, Y.-J. Effects of far infrared radiation drying on antioxidant and anticoagulant activities of ecklonia cava extracts. J. Korean Soc. Appl. Biol. Chem. 2010, 53, 175-183. [CrossRef]

83. Medeiros, V.P.; Queiroz, K.C.; Cardoso, M.L.; Monteiro, G.R.; Oliveira, F.W.; Chavante, S.F.; Guimaraes, L.A.; Rocha, H.A.; Leite, E.L. Sulfated galactofucan from lobophora variegata: Anticoagulant and anti-inflammatory properties. Biochemistry 2008, 73, 1018-1024. [CrossRef]

84. Millet, J.; Jouault, S.C.; Mauray, S.; Theveniaux, J.; Sternberg, C.; Boisson Vidal, C.; Fischer, A.M. Antithrombotic and anticoagulant activities of a low molecular weight fucoidan by the subcutaneous route. Thromb. Haemost. 1999, 81, 391-395. [CrossRef]

85. Nishino, T.; Aizu, Y.; Nagumo, T. Antithrombin activity of a fucan sulfate from the brown seaweed ecklonia kurome. Thromb. Res. 1991, 62, 765-773. [CrossRef]

86. Rocha, H.A.; Moraes, F.A.; Trindade, E.S.; Franco, C.R.; Torquato, R.J.; Veiga, S.S.; Valente, A.P.; Mourao, P.A.; Leite, E.L.; Nader, H.B.; et al. Structural and hemostatic activities of a sulfated galactofucan from the brown alga spatoglossum schroederi. An ideal antithrombotic agent? J. Biol. Chem. 2005, 280, 41278-41288. [CrossRef]

87. Rupérez, P.; Ahrazem, O.; Leal, J.A. Potential antioxidant capacity of sulfated polysaccharides from the edible marine brown seaweed fucus vesiculosus. J. Agric. Food. Chem. 2002, 50, 840-845. [CrossRef]

88. Trento, F.; Cattaneo, F.; Pescador, R.; Porta, R.; Ferro, L. Antithrombin activity of an algal polysaccharide. Thromb. Res. 2001, 102, 457-465. [CrossRef]

89. Yoon, S.J.; Pyun, Y.R.; Hwang, J.K.; Mourao, P.A. A sulfated fucan from the brown alga laminaria cichorioides has mainly heparin cofactor ii-dependent anticoagulant activity. Carbohydr. Res. 2007, 342, 2326-2330. [CrossRef]

90. Zoysa, M.D.; Nikapitiya, C.; Jeon, Y.-J.; Jee, Y.; Lee, J. Anticoagulant activity of sulfated polysaccharide isolated from fermented brown seaweed sargassum fulvellum. J. Appl. Phycol. 2008, 20, 67-74. [CrossRef]

91. Carlucci, M.J.; Pujol, C.A.; Ciancia, M.; Noseda, M.D.; Matulewicz, M.C.; Damonte, E.B.; Cerezo, A.S. Antiherpetic and anticoagulant properties of carrageenans from the red seaweed gigartina skottsbergii and their cyclized derivatives: Correlation between structure and biological activity. Int. J. Biol. Macromol. 1997, 20, 97-105. [CrossRef]

92. Ekanayake, P.M.; Nikapitiya, C.; De Zoysa, M.; Jeon, Y.J.; Lee, J. Isolation and purification of an anticoagulant from schizymenia dubyi by fermentation. Food Sci. Technol. Int. 2007, 13, 355-359. [CrossRef]

93. Ekanayake, P.M.; Nikapitiya, C.; De Zoysa, M.; Whang, I.; Kim, S.J.; Lee, J. Novel anticoagulant compound from fermented red alga pachymeniopsis elliptica. Eur. Food Res. Technol. 2008, 227, 897-903. [CrossRef] 
94. Farias, W.R.; Valente, A.P.; Pereira, M.S.; Mourao, P.A. Structure and anticoagulant activity of sulfated galactans. Isolation of a unique sulfated galactan from the red algae botryocladia occidentalis and comparison of its anticoagulant action with that of sulfated galactans from invertebrates. J. Biol. Chem. 2000, 275, 29299-29307. [CrossRef]

95. Gómez-Ordóñez, E.; Jiménez-Escrig, A.; Rupérez, P. Bioactivity of sulfated polysaccharides from the edible red seaweed mastocarpus stellatus. Bioact. Carbohydr. Dietary Fibre 2014, 3, 29-40. [CrossRef]

96. Kolender, A.A.; Pujol, C.A.; Damonte, E.B.; Matulewicz, M.C.; Cerezo, A.S. The system of sulfated $\alpha-(1 \rightarrow$ 3)-linked-mannans from the red seaweed nothogenia fastigiata: Structures, antiherpetic and anticoagulant properties. Carbohydr. Res. 1997, 304, 53-60. [CrossRef]

97. Usov, A.I. Polysaccharides of the red algae. Adv Carbohydr Chem Biochem. 2011, 65, 115-217. [CrossRef]

98. Melo, F.R.; Pereira, M.S.; Foguel, D.; Mourao, P.A. Antithrombin-mediated anticoagulant activity of sulfated polysaccharides: Different mechanisms for heparin and sulfated galactans. J. Biol. Chem. 2004, 279, 20824-20835. [CrossRef] [PubMed]

99. Pereira, M.G.; Benevides, N.M.; Melo, M.R.; Valente, A.P.; Melo, F.R.; Mourao, P.A. Structure and anticoagulant activity of a sulfated galactan from the red alga, gelidium crinale. Is there a specific structural requirement for the anticoagulant action? Carbohydr. Res. 2005, 340, 2015-2023. [CrossRef]

100. Pushpamali, W.A.; Nikapitiya, C.; Zoysa, M.D.; Whang, I.; Kim, S.J.; Lee, J. Isolation and purification of an anticoagulant from fermented red seaweed lomentaria catenata. Carbohydr. Polym. 2008, 73, 274-279. [CrossRef]

101. Sebaaly, C.; Kassem, S.; Grishina, E.; Kanaan, H.; Sweidan, A.; Chmit, M.S.; Kanaan, H.M. Anticoagulant and antibacterial activities of polysaccharides of red algae corallina collected from lebanese coast. J. Appl. Pharm. Sci. 2014, 4, 30-37. [CrossRef]

102. Sen, A.K., Sr.; Das, A.; Banerji, N.; Siddhanta, A.; Mody, K.; Ramavat, B.; Chauhan, V.; Vedasiromoni, J.; Ganguly, D. A new sulfated polysaccharide with potent blood anti-coagulant activity from the red seaweed grateloupia indica. Br. J. Pharmacol. Chemother. 1994, 16, 279-280. [CrossRef]

103. Talarico, L.B.; Duarte, M.E.; Zibetti, R.G.; Noseda, M.D.; Damonte, E.B. An algal-derived dl-galactan hybrid is an efficient preventing agent for in vitro dengue virus infection. Planta Med. 2007, 73, 1464-1468. [CrossRef]

104. Harada, N.; Maeda, M. Chemical structure of antithrombin-active rhamnan sulfate from monostrom nitidum. Biosci. Biotechnol. Biochem. 1998, 62, 1647-1652. [CrossRef] [PubMed]

105. Hayakawa, Y.; Hayashi, T.; Lee, J.-B.; Srisomporn, P.; Maeda, M.; Ozawa, T.; Sakuragawa, N. Inhibition of thrombin by sulfated polysaccharides isolated from green algae. Biochim. Biophys. Acta 2000, 1543, 86-94. [CrossRef]

106. Jurd, K.M.; Rogers, D.J.; Blunden, G.; McLellan, D.S. Anticoagulant properties of sulphated polysaccharides and a proteoglycan from codium fragile ssp. Atlanticum. J. Appl. Phycol. 1995, 7, 339. [CrossRef]

107. Lee, J.-B.; Yamagaki, T.; Maeda, M.; Nakanishi, H. Rhamnan sulfate from cell walls of monostroma latissimum. Phytochemistry 1998, 48, 921-925. [CrossRef]

108. Li, N.; Mao, W.; Yan, M.; Liu, X.; Xia, Z.; Wang, S.; Xiao, B.; Chen, C.; Zhang, L.; Cao, S. Structural characterization and anticoagulant activity of a sulfated polysaccharide from the green alga codium divaricatum. Carbohydr. Polym. 2015, 121, 175-182. [CrossRef] [PubMed]

109. Maeda, M.; Uehara, T.; Harada, N.; Sekiguchi, M.; Hiraoka, A. Heparinoid-active sulphated polysaccharides from monostroma nitidum and their distribution in the chlorophyta. Phytochemistry 1991, 30, 3611-3614. [CrossRef]

110. Mao, W.; Li, H.; Li, Y.; Zhang, H.; Qi, X.; Sun, H.; Chen, Y.; Guo, S. Chemical characteristic and anticoagulant activity of the sulfated polysaccharide isolated from monostroma latissimum (chlorophyta). Int. J. Biol. Macromol. 2009, 44, 70-74. [CrossRef] [PubMed]

111. Mao, W.; Zang, X.; Li, Y.; Zhang, H. Sulfated polysaccharides from marine green algae ulva conglobata and their anticoagulant activity. J. Appl. Phycol. 2006, 18, 9-14. [CrossRef]

112. Mao, W.-J.; Fang, F.; Li, H.-Y.; Qi, X.-H.; Sun, H.-H.; Chen, Y.; Guo, S.-D. Heparinoid-active two sulfated polysaccharides isolated from marine green algae monostroma nitidum. Carbohydr. Polym. 2008, 74, 834-839. [CrossRef]

113. Matsubara, K. An anticoagulant proteogylcan from the marine green alga, codium pungniformis. J. Appl. Phycol. 2000, 9-14. [CrossRef] 
114. Matsubara, K.; Hori, K.; Matsuura, Y.; Miyazawa, K. Purification and characterization of a fibrinolytic enzyme and identification of fibrinogen clotting enzyme in a marine green alga, codium divaricatum. Comp. Biochem. Physiol. B Biochem. Mol. Biol. 2000, 125, 137-143. [CrossRef]

115. Qi, X.; Mao, W.; Gao, Y.; Chen, Y.; Chen, Y.; Zhao, C.; Li, N.; Wang, C.; Yan, M.; Lin, C.; et al. Chemical characteristic of an anticoagulant-active sulfated polysaccharide from enteromorpha clathrata. Carbohydr. Polym. 2012, 90, 1804-1810. [CrossRef] [PubMed]

116. Rodrigues, J.A.; Vanderlei, E.D.; Bessa, É.F.; Magalhães, F.D.; Paula, R.C.; Lima, V.; Benevides, N.M. Anticoagulant activity of a sulfated polysaccharide isolated from the green seaweed caulerpa cupressoides. Braz. Arch. Biol. Technol. 2011, 54, 691-700. [CrossRef]

117. Rogers, D.J.; Jurd, K.M.; Blunden, G.; Paoletti, S.; Zanetti, F. Anticoagulant activity of a proteoglycan in extracts ofcodium fragile ssp.Atlanticum. J. Appl. Phycol. 1990, 2, 357-361. [CrossRef]

118. Siddhanta, A.K.; Shanmugam, M.; Mody, K.H.; Goswami, A.M.; Ramavat, B.K. Sulphated polysaccharides of codium dwarkense boergs. From the west coast of india: Chemical composition and blood anticoagulant activity. Int. J. Biol. Macromol. 1999, 26, 151-154. [CrossRef]

119. Raposo, M.; de Morais, R.; Bernardo de Morais, A. Bioactivity and applications of sulphated polysaccharides from marine microalgae. Mar. Drugs 2013, 11, 233. [CrossRef]

120. Raposo, M.F.d.J.; de Morais, A.M.M.B. Microalgae for the prevention of cardiovascular disease and stroke. Life Sciences 2015, 125, 32-41. [CrossRef] [PubMed]

121. Yu, Y.; Shen, M.; Song, Q.; Xie, J. Biological activities and pharmaceutical applications of polysaccharide from natural resources: A review. Carbohydr. Polym. 2018, 183, 91-101. [CrossRef] [PubMed]

122. Cai, Y.; Yang, W.; Yin, R.; Zhou, L.; Li, Z.; Wu, M.; Zhao, J. An anticoagulant fucan sulfate with hexasaccharide repeating units from the sea cucumber holothuria albiventer. Carbohydr. Res. 2018, 464, 12-18. [CrossRef]

123. Chen, S.; Hu, Y.; Ye, X.; Li, G.; Yu, G.; Xue, C.; Chai, W. Sequence determination and anticoagulant and antithrombotic activities of a novel sulfated fucan isolated from the sea cucumber isostichopus badionotus. Biochim. Biophys. Acta 2012, 1820, 989-1000. [CrossRef]

124. Mourao, P.A.; Giumaraes, B.; Mulloy, B.; Thomas, S.; Gray, E. Antithrombotic activity of a fucosylated chondroitin sulphate from echinoderm: Sulphated fucose branches on the polysaccharide account for its antithrombotic action. Br. J. Haematol. 1998, 101, 647-652. [CrossRef] [PubMed]

125. Mourao, P.A.; Pereira, M.S.; Pavao, M.S.; Mulloy, B.; Tollefsen, D.M.; Mowinckel, M.C.; Abildgaard, U. Structure and anticoagulant activity of a fucosylated chondroitin sulfate from echinoderm. Sulfated fucose branches on the polysaccharide account for its high anticoagulant action. J. Biol. Chem. 1996, 271, 23973-23984. [CrossRef] [PubMed]

126. Pereira, M.S.; Vilela-Silva, A.C.; Valente, A.P.; Mourao, P.A. A 2-sulfated, 3-linked alpha-1-galactan is an anticoagulant polysaccharide. Carbohydr. Res. 2002, 337, 2231-2238. [CrossRef]

127. Vilela-Silva, A.-C.E.S.; Castro, M.O.; Valente, A.-P.; Biermann, C.H.; Mourão, P.A.S. Sulfated fucans from the egg jellies of the closely related sea urchins strongylocentrotus droebachiensis and strongylocentrotus pallidus ensure species-specific fertilization. J. Biol. Chem. 2002, 277, 379-387. [CrossRef] [PubMed]

128. Wu, M.; Xu, L.; Zhao, L.; Xiao, C.; Gao, N.; Luo, L.; Yang, L.; Li, Z.; Chen, L.; Zhao, J. Structural analysis and anticoagulant activities of the novel sulfated fucan possessing a regular well-defined repeating unit from sea cucumber. Mar. Drugs 2015, 13, 2063-2084. [CrossRef]

129. Zhao, J.; Yang, J.; Song, S.; Zhou, D.; Qiao, W.; Zhu, C.; Liu, S.; Zhu, B. Anticoagulant activity and structural characterization of polysaccharide from abalone (haliotis discus hannai ino) gonad. Molecules 2016, 21, 697. [CrossRef] [PubMed]

130. Pomin, V.H. Fucanomics and galactanomics: Marine distribution, medicinal impact, conceptions, and challenges. Mar. Drugs 2012, 10, 793-811. [CrossRef] [PubMed]

131. Pomin, V.H. Marine medicinal glycomics. Front. Cell. Infect. Microbiol. 2014, 4, 5. [CrossRef] [PubMed]

132. Pomin, V.H. Fucanomics and galactanomics: Current status in drug discovery, mechanisms of action and role of the well-defined structures. Biochim. Biophys. Acta 2012, 1820, 1971-1979. [CrossRef] [PubMed]

133. Fonseca, R.J.; Oliveira, S.N.; Melo, F.R.; Pereira, M.G.; Benevides, N.M.; Mourao, P.A. Slight differences in sulfation of algal galactans account for differences in their anticoagulant and venous antithrombotic activities. Thromb. Haemost. 2008, 99, 539-545. [CrossRef]

134. Pomin, V.H. Review: An overview about the structure-function relationship of marine sulfated homopolysaccharides with regular chemical structures. Biopolymers 2009, 91, 601-609. [CrossRef] [PubMed] 
135. Bilan, M.I.; Ustyuzhanina, N.E.; Shashkov, A.S.; Thanh, T.T.T.; Bui, M.L.; Tran, T.T.V.; Bui, V.N.; Usov, A.I. Sulfated polysaccharides of the vietnamese brown alga sargassum aquifolium (fucales, sargassaceae). Carbohydr. Res. 2017, 449, 23-31. [CrossRef] [PubMed]

136. Morelli, A.; Puppi, D.; Chiellini, F. Chapter 16-Perspectives on biomedical applications of ulvan. In Seaweed Polysaccharides; Venkatesan, J., Anil, S., Kim, S.-K., Eds.; Elsevier: Amsterdam, The Netherlands, 2017; pp. 305-330.

137. Synytsya, A.; Choi, D.J.; Pohl, R.; Na, Y.S.; Capek, P.; Lattová, E.; Taubner, T.; Choi, J.W.; Lee, C.W.; Park, J.K.; et al. Structural features and anti-coagulant activity of the sulphated polysaccharide sps-cf from a green alga capsosiphon fulvescens. Mar. Biotechnol. 2015, 17, 718-735. [CrossRef] [PubMed]

138. Tang, L.; Chen, Y.; Jiang, Z.; Zhong, S.; Chen, W.; Zheng, F.; Shi, G. Purification, partial characterization and bioactivity of sulfated polysaccharides from grateloupia livida. Int. J. Biol. Macromol. 2017, 94, 642-652. [CrossRef] [PubMed]

139. Pereira, M.S.; Melo, F.R.; Mourão, P.A.S. Is there a correlation between structure and anticoagulant action of sulfated galactans and sulfated fucans? Glycobiology 2002, 12, 573-580. [CrossRef] [PubMed]

140. Karasudani, I.; Koyama, T.; Nakandakari, S.; Aniya, Y. Purification of anticoagulant factor from the spine venom of the crown-of-thorns starfish, acanthaster planci. Toxicon 1996, 34, 871-879. [CrossRef]

141. Carroll, A.R.; Pierens, G.K.; Fechner, G.; de Almeida Leone, P.; Ngo, A.; Simpson, M.; Hyde, E.; Hooper, J.N.; Boström, S.-L.; Musil, D. Dysinosin a: A novel inhibitor of factor viia and thrombin from a new genus and species of australian sponge of the family dysideidae. J. Am. Chem. Soc. 2002, 124, 13340-13341. [CrossRef]

142. Indumathi, P.; Mehta, A. A novel anticoagulant peptide from the nori hydrolysate. J. Funct. Foods 2016, 20, 606-617. [CrossRef]

143. Francischetti, I.M. Platelet aggregation inhibitors from hematophagous animals. Toxicon 2010, 56, 1130-1144. [CrossRef] [PubMed]

144. Markwardt, F. State-of-the-art review: Antithrombotic agents from hematophagous animals. Clin. Appl. Thromb. Hemost. 1996, 2, 75-82. [CrossRef]

145. Kimura, J.; Ishizuka, E.; Nakao, Y.; Yoshida, W.Y.; Scheuer, P.J.; Kelly-Borges, M. Isolation of 1-methylherbipoline salts of halisulfate-1 and of suvanine as serine protease inhibitors from a marine sponge, coscinoderma mathewsi. J. Nat. Prod. 1998, 61, 248-250. [CrossRef]

146. Park, B.G.; Shin, W.S.; Um, Y.; Cho, S.; Park, G.M.; Yeon, D.S.; Kwon, S.C.; Ham, J.; Choi, B.W.; Lee, S. Selective vasodilatation effect of sargahydroquinoic acid, an active constituent of sargassum micracanthum, on the basilar arteries of rabbits. Bioorg. Med. Chem. Lett. 2008, 18, 2624-2627. [CrossRef]

147. Kim, S.N.; Choi, H.Y.; Lee, W.; Park, G.M.; Shin, W.S.; Kim, Y.K. Sargaquinoic acid and sargahydroquinoic acid from sargassum yezoense stimulate adipocyte differentiation through pparalpha/gamma activation in 3t3-11 cells. FEBS Lett. 2008, 582, 3465-3472. [CrossRef]

148. de Andrade Moura, L.; Marqui de Almeida, A.C.; Domingos, T.F.S.; Ortiz-Ramirez, F.; Cavalcanti, D.N.; Teixeira, V.L.; Fuly, A.L. Antiplatelet and anticoagulant effects of diterpenes isolated from the marine alga, dictyota menstrualis. Mar. Drugs 2014, 12, 2471-2484. [CrossRef]

149. Huryn, D.M.; Wipf, P. Natural product chemistry and cancer drug discovery. In Cancer Drug Design and Discovery, 2nd ed.; Neidle, S., Ed.; Academic Press: San Diego, CA, USA, 2014; pp. 91-120.

150. Villar, R.M.; Gil-Longo, J.; Daranas, A.H.; Souto, M.L.; Fernandez, J.J.; Peixinho, S.; Barral, M.A.; Santafe, G.; Rodriguez, J.; Jimenez, C. Evaluation of the effects of several zoanthamine-type alkaloids on the aggregation of human platelets. Biorg. Med. Chem. 2003, 11, 2301-2306. [CrossRef]

151. Gulavita, N.K.; Pomponi, S.A.; Wright, A.E.; Garay, M.; Sills, M.A. Aplysillin a, a thrombin receptor antagonist from the marine sponge aplysina fistularis fulva. J. Nat. Prod. 1995, 58, 954-957. [CrossRef]

152. Glombitza, K.W.; Hauperich, S.; Keusgen, M. Phlorotannins from the brown algae cystophora torulosa and sargassum spinuligerum. Nat. Toxins 1997, 5, 58-63. [CrossRef]

153. Chang, M.-C.; Chang, H.-H.; Chan, C.-P.; Chou, H.-Y.; Chang, B.-E.; Yeung, S.-Y.; Wang, T.-M.; Jeng, J.-H. Antiplatelet effect of phloroglucinol is related to inhibition of cyclooxygenase, reactive oxygen species, erk/p38 signaling and thromboxane a2 production. Toxicol. Appl. Pharmacol. 2012, 263, 287-295. [CrossRef]

154. Gould, W.R.; McClanahan, T.B.; Welch, K.M.; Baxi, S.M.; Saiya-Cork, K.; Chi, L.; Johnson, T.R.; Leadley, R.J. Inhibitors of blood coagulation factors $x a$ and iia synergize to reduce thrombus weight and thrombin generation in vivo and in vitro. J. Thromb. Haemost. 2006, 4, 834-841. [CrossRef] 
155. Nar, H.; Bauer, M.; Schmid, A.; Stassen, J.M.; Wienen, W.; Priepke, H.W.; Kauffmann, I.K.; Ries, U.J.; Hauel, N.H. Structural basis for inhibition promiscuity of dual specific thrombin and factor xa blood coagulation inhibitors. Structure 2001, 9, 29-37. [CrossRef]

156. Deng, J.Z.; McMasters, D.R.; Rabbat, P.M.; Williams, P.D.; Coburn, C.A.; Yan, Y.; Kuo, L.C.; Lewis, S.D.; Lucas, B.J.; Krueger, J.A.; et al. Development of an oxazolopyridine series of dual thrombin/factor xa inhibitors via structure-guided lead optimization. Bioorg. Med. Chem. Lett. 2005, 15, 4411-4416. [CrossRef] [PubMed]

157. Andersen, R.J.; Allen, T.M.; Burgoyne, D.L. Contignasterol, and Related 3-alpha hydroxy-6-alpha hydroxy-7-beta hydroxy-15-keto-14-beta Steroids Useful as Anti-Inflammatory and Anti-Thrombosis Agents. U.S. Patent 5,506,221, 1996.

158. Stead, P.; Hiscox, S.; Robinson, P.S.; Pike, N.B.; Sidebottom, P.J.; Roberts, A.D.; Taylor, N.L.; Wright, A.E.; Pomponi, S.A.; Langley, D. Eryloside f, a novel penasterol disaccharide possessing potent thrombin receptor antagonist activity. Bioorg. Med. Chem. Lett. 2000, 10, 661-664. [CrossRef]

159. Yang, S.-W.; Buivich, A.; Chan, T.-M.; Smith, M.; Lachowicz, J.; Pomponi, S.A.; Wright, A.E.; Mierzwa, R.; Patel, M.; Gullo, V. A new sterol sulfate, sch 572423, from a marine sponge, topsentia sp. Bioorg. Med. Chem. Lett. 2003, 13, 1791-1794. [CrossRef]

160. Damman, P.; Woudstra, P.; Kuijt, W.J.; de Winter, R.J.; James, S.K. P2y12 platelet inhibition in clinical practice. J. Thromb. Thrombolysis 2012, 33, 143-153. [CrossRef] [PubMed]

161. Tachibana, K.; Scheuer, P.J.; Tsukitani, Y.; Kikuchi, H.; Van Engen, D.; Clardy, J.; Gopichand, Y.; Schmitz, F.J. Okadaic acid, a cytotoxic polyether from two marine sponges of the genus halichondria. J. Am. Chem. Soc. 1981, 103, 2469-2471. [CrossRef]

162. Karaki, H.; Mitsui, M.; Nagase, H.; Ozaki, H.; Shibata, S.; Uemura, D. Inhibitory effect of a toxin okadaic acid, isolated from the black sponge on smooth muscle and platelets. Br. J. Pharmacol. 1989, 98, 590-596. [CrossRef] [PubMed]

163. Cohen, P.; Holmes, C.F.; Tsukitani, Y. Okadaic acid: A new probe for the study of cellular regulation. Trends Biochem. Sci. 1990, 15, 98-102. [CrossRef]

164. Pimentel, S.M.; Bojo, Z.P.; Roberto, A.V.; Lazaro, J.E.; Mangalindan, G.C.; Florentino, L.M.; Lim-Navarro, P.; Tasdemir, D.; Ireland, C.M.; Concepcion, G.P. Platelet aggregation inhibitors from philippine marine invertebrate samples screened in a new microplate assay. Mar. Biotechnol. 2003, 5, 395-400. [CrossRef] [PubMed]

165. Jung, W.-K.; Athukorala, Y.; Lee, Y.-J.; Cha, S.H.; Lee, C.-H.; Vasanthan, T.; Choi, K.-S.; Yoo, S.-H.; Kim, S.-K.; Jeon, Y.-J. Sulfated polysaccharide purified from ecklonia cava accelerates antithrombin iii-mediated plasma proteinase inhibition. J. Appl. Phycol. 2007, 19, 425-430. [CrossRef] 